\title{
Treatment of statins drug (pravastatin and rosuvastatin) in water by electro-Fenton process: Kinetics of degradation/mineralization and optimization of experimental conditions for a biological post-treatment
}

\author{
Nisrine Beqqal ${ }^{1, *}$, Muna Sh. Yahya ${ }^{2}$, Miloud El Karbane ${ }^{3}$, Hind Chakchak ${ }^{4}$ and Kacem El Kacemi ${ }^{1}$ \\ ${ }^{1}$ Laboratoire d'Électrochimie et Chimie Analytique (LECA), Faculté des Sciences, Université Mohammed V \\ Rabat, Maroc \\ ${ }^{2}$ Department of Chemistry, Faculty of Education, Hodeidah University, Hodeida, Yemen \\ ${ }^{3}$ Laboratoire de chimie analytique et de bromatologie, Faculté de médecine et de pharmacie de l'Université \\ Mohamed V, Rabat, Maroc \\ ${ }^{4}$ Centre national pour la recherche scientifique et technique (CNRST-UATRS), Rabat, Maroc
}

\begin{abstract}
The treatment of pravastatin and rosuvastatin contaminated water as much as toxic and persistent organic pollutant was carried out by Electro-Fenton method EF. Several experiments were conducted in a cell compartment equipped with a platinum anode and a carbon felt cathode. The effects of several parameters such as the applied current and the catalyst $\mathrm{Fe}^{2+}$ concentration have been studied. Mineralization aqueous solutions of pravastatin followed by the chemical oxygen demand COD gave a higher degree of reduction of more than $90 \%$ for 6 hours of treatment at a current of $100 \mathrm{~mA}$ and $\mathrm{Fe}^{2+}$ concentration of $0.2 \mathrm{mM}$. The study of the degradation kinetics was followed during electrolysis by HPLC giving a pseudo first order reaction using a current of 100 $\mathrm{mA}$ and $\mathrm{Fe}^{2+}$ concentration of $0.1 \mathrm{mM}$. A number of intermediate products for pravastatin and rosuvastatin have been identified using HPLC and liquid chromatography-mass spectrometry analyses. Biodegradability of the pretreated solutions of two statins by EF was evaluated in order to decide the optimal moment to introduce the biological process. It was given by the ratio $\mathrm{BOD}_{5} / \mathrm{COD}$ which increases from 0 initially to 1.3 after 2 hours for pravastatin and from 0 initially to 1.5 after 3 hours for rosuvastatin as the COD decreases. It implies that EF tends to enhance the biodegradability and could be used as a pre-treatment step for biological treatment.
\end{abstract}

Keywords: pravastatin; rosuvastatin; Electro-Fenton; degradation; mineralization; biodegradability.

\section{Introduction}

Pharmaceuticals account for a large group of human and veterinary drugs used in the world. The sale is estimated at 250 billion $\$$ annually ${ }^{1}$, hence their presence in the environment has become a major research topic and highlighted in the United States in the 1970s ${ }^{2,3}$ and meadows a decade later in England ${ }^{4}$. The penetration of these products in the environment can occur through different routes leading to pollution. The sources of this contamination involve the elimination of drugs in waste production and water treatment ${ }^{5}$. The inefficiency of conventional physicochemical methods in sewage treatment plants for disposal of medicines leads to their accumulation in the environment ${ }^{6}$. Despite their very low content in natural waters, their presence is very toxic for the biological hierarchy. This finding was demonstrated by the production of multi-resistant strains of microorganisms by certain drugs and their adverse effects on the endocrine system of fish and invertebrates and algae ${ }^{7}$. Statins are a group of medicines used to lower cholesterol levels in the blood, prescribed to patients at risk of coronary heart disease for the reduction of morbidity and cardiovascular mortality. The presence of these medicines in water has been well-covered by several studies ${ }^{8}$. A recent research has shown that statins have potential anti-cancer effects ${ }^{9,10}$. Because of their reluctance in wastewater treatment systems, their widespread presence and their high persistence, these drugs have been detected in untreated wastewater to $4-49 \mathrm{ng} / \mathrm{L}$, in the treated wastewater 1$59 \mathrm{ng} / \mathrm{L}$ and even in the drinking water ${ }^{8-11,12}$. Due to their toxicity to humans and other forms of life, there is a strong need to treat all effluents contaminated by these pollutants before their admission in the environment ${ }^{13}$. 
Previously, a number of advanced oxidation processes (AOP) were evaluated for the disposal of pharmaceuticals in water ${ }^{14-18}$. AOPs are effective methods that generate hydroxyl radicals in situ ${ }^{\bullet} \mathrm{OH}$ capable to oxidize organic molecules until their mineralization. These radicals may be produced by chemical, photochemical or electrochemical methods 19-21

Recently, electrochemical methods based on the Fenton reaction such as electro-Fenton (EF) have shown promising results in the degradation of organic matter in water through their simplicity, high efficiency and relatively low cost ${ }^{22,23}$. This has been demonstrated for several pollutants, including phenols ${ }^{24,25}$, synthetic dyes ${ }^{26}$, herbicides and pesticides $^{27,28}$ and drugs ${ }^{29-33}$.

EF method is based on the addition of a catalytic amount of $\mathrm{Fe}^{2+}$ in an acid solution contained in an electrolytic cell continuously producing $\mathrm{H}_{2} \mathrm{O}_{2}$ from $\mathrm{O}_{2}$ injected at the cathode according to the reaction (1) ${ }^{31}$. The reaction between $\mathrm{Fe}^{2+}$ and $\mathrm{H}_{2} \mathrm{O}_{2}$ gives $\mathrm{Fe}^{3+}$ and the hydroxyl radical ${ }^{\bullet} \mathrm{OH}$ according to Fenton's reaction (2). ${ }^{\bullet} \mathrm{OH}$ is considered to be the strongest oxidizing following its high standard reduction potential $\left(\mathrm{E}^{\circ}\left({ }^{\bullet} \mathrm{OH} / \mathrm{H}_{2} \mathrm{O}\right)=2.80 \mathrm{~V} / \mathrm{ENH}\right)$ and has no selectivity for reacting with the organic compounds until mineralization giving carbon dioxide, water and inorganic ions.

$$
\begin{aligned}
& \mathrm{O}_{2}+2 \mathrm{e}^{-}+2 \mathrm{H}^{+} \rightarrow \mathrm{H}_{2} \mathrm{O}_{2} \\
& \mathrm{H}_{2} \mathrm{O}_{2}+\mathrm{Fe}^{2^{+}} \rightarrow \mathrm{Fe}^{3+}+{ }^{\bullet} \mathrm{OH}+\mathrm{OH}^{-} \\
& \mathrm{Fe}^{3+}+\mathrm{e}^{-} \rightarrow \mathrm{Fe}^{2+}
\end{aligned}
$$

In the present paper, we choose to study the case of PRA of the first generation and ROS of the $3^{\text {rd }}$ generation as a model of statin known by their large volume production, high consumption, highly toxic and potentially carcinogenic ${ }^{34,35}$. Our primary objectives are to determine the degradation kinetics and efficiency of mineralization of acidic aqueous solutions of PRA by Electro-Fenton process, knowing that this study was already done in the first article for ROS ${ }^{17}$ which The decay kinetics of ROS followed pseudo-first order reaction and an optimum current of $300 \mathrm{~mA}$ and a catalyst $\left(\mathrm{Fe}^{3+}\right)$ concentration of $0.2 \mathrm{mM}$ were found to be optimal for an effective degradation. The identification of the intermediates and the study of the biodegradability were carried out for both statins.

Table 1. Pravastatin sodium (PRA) and Rosuvastatin calcium (ROS) properties

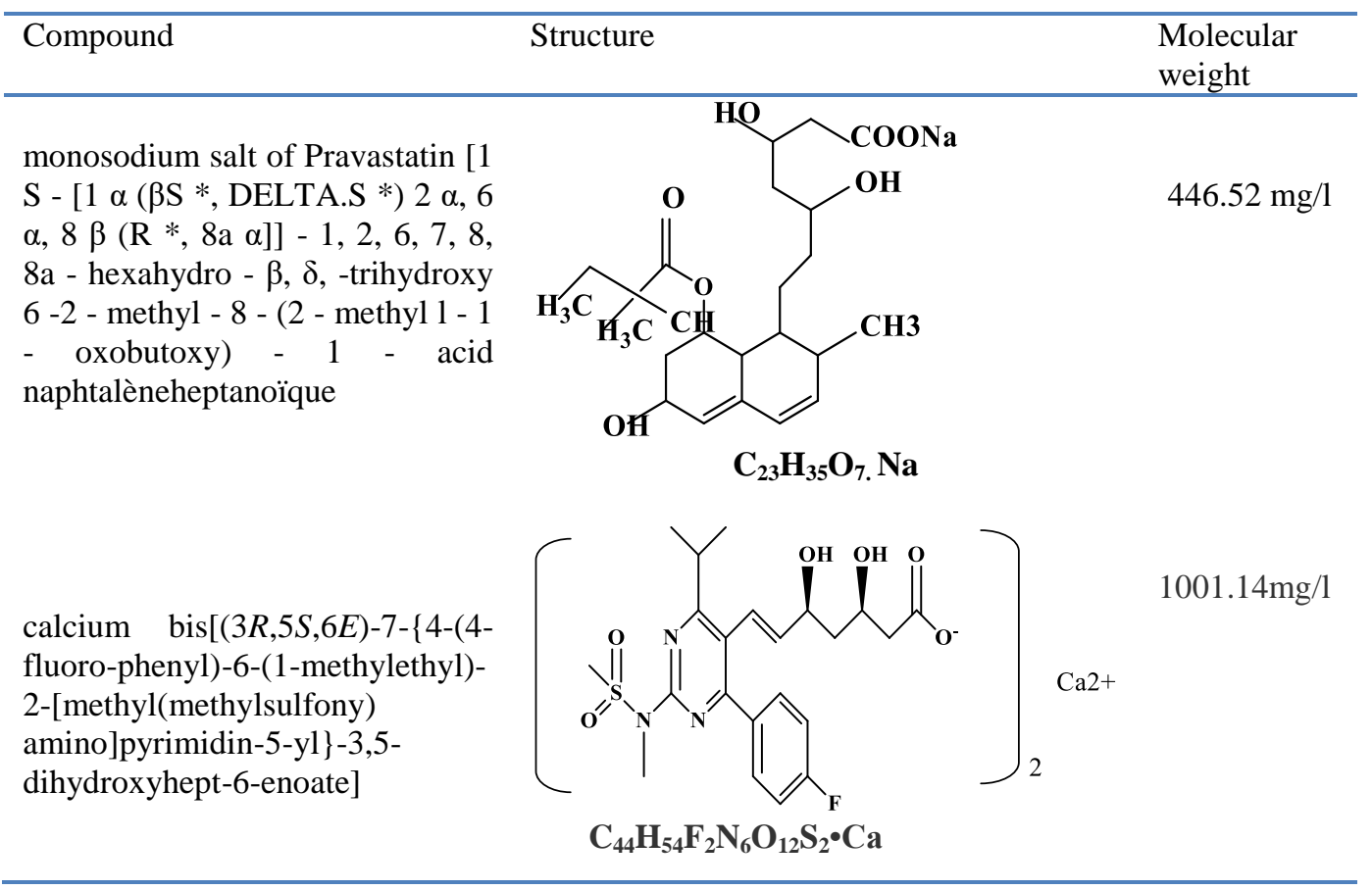

\section{Experimental Section}

\section{Chemicals}

Pravastatin sodium PRA (98\%) and Rosuvastatin calcium (98\%) were purchased from Sigma Aldrich and used without purification. there chemical structures and physical properties were given in Table 1. Anhydrous sodium sulfate $\mathrm{Na}_{2} \mathrm{SO}_{4}$ used as supporting electrolyte is of analytical grade from
Sigma Aldrich. Heptahydrated ferrous sulfate and pentahydrated ferrous sulfate used as catalyst is of analytical grade from Shangai Chemical Reagents Co. Solutions were prepared with high-purity water obtained from a Millipore Milli-Q system with resistivity $>18 \mathrm{M} \Omega$ at $25^{\circ} \mathrm{C}$ and were adjusted to $\mathrm{pH}$ 3.0 with analytical grade sulfuric acid from Merck using HANNA pH-meter. Other chemicals such as methanol, Triéthylamin, and acetic acid (HPLC grade, Sigma Aldrich), Acetonitril (ACN) 
(HPLC grade, Carlo erpa), were used as received. Potassium chloride $(\mathrm{KCl})$, Mercuric sulfate $\mathrm{HgSO}_{4}$, silver sulfate $\mathrm{AgSO}_{4}$ and potassium dichromate $\mathrm{K}_{2} \mathrm{CrO}_{7}$ were purchased from Hach Lange Europe, Belgium.

\section{Electrolytic system}

The experiments were performed using a cylindrical and open undivided cell of $6 \mathrm{~cm}$ diameter and $250 \mathrm{ml}$ capacity in which statins aqueous solutions were placed. The cathode is $70 \mathbf{~ c m}^{2}(\mathbf{1 0} \mathbf{~ c m}$ $\times 7 \mathrm{~cm})$ carbon felt piece (carbon Lorraine) with a thickness of $0.5 \mathrm{~cm}$, and the anode is a platinum 5 $\mathbf{c m}^{2}$. The anode is centered in the electrolytic cell and surrounded by the cathode. The electrodes were connected to a Potentiostat model / Galvanostat PGZ301 associated with "VoltaLab" to control the current intensity. A saturated calomel electrode (SCE) was used as reference. Electrolysis was conducted with a volume of $200 \mathrm{ml}$ of aqueous solution, while stirring vigorously with a magnetic stirrer and a rotation rate of 700 revolutions / minute for mass transfer. Sparging with compressed air for 10 minutes through the solution is needed to saturate the aqueous solution before the electrolysis. The aqueous solutions contain $0.05 \mathrm{M}$ of $\mathrm{Na}_{2} \mathrm{SO}_{4}, 0.1 \mathrm{mM}$ of $\mathrm{Fe}^{2+}$ and $0.2 \mathrm{mM}$ of $\mathrm{Fe}^{3+}$ were added for PRA and ROS, respectively. The study was brought to room temperature and applying a constant current in the range of 30 to $300 \mathrm{~mA}$ at $\mathrm{pH} 3$ considered as the recommended value for the EF process ${ }^{36}$.

\section{Analytical procedures}

The PRA concentration during electrolysis was quantified by high performance liquid chromatography (HPLC), using a waters 2695, fitted with Thermo Hypersil C18 column $250 \mathrm{~mm} / 4.6 \mathrm{~mm} / 5 \mu \mathrm{m}$ at $25{ }^{\circ} \mathrm{C}$, and coupled with photodiode array PDA 2998 detector selected at optimum wavelengths of $238 \mathrm{~nm}$. The sample volumes were $50 \quad \mu \mathrm{L}$. Acetic acid/triéthylamin/methanol/water $\quad 1: 1: 450: 550$ $(\mathrm{v} / \mathrm{v} / \mathrm{v} / \mathrm{v})$ mixture was used as a mobile phase at a flow rate of $1.3 \mathrm{ml} / \mathrm{min}$. the corresponding retention time $\left(\mathrm{t}_{\mathrm{r}}\right)$ for PRA was $18 \mathrm{~min}$.

The evolution of Rosuvastatin concentrations was detected using a Waters 2695, fitted with Zorbax eclipse XDB C18 column $(150 \mathrm{~mm} / 4.6 \mathrm{~mm} / 3.5 \mu \mathrm{m})$ at $25^{\circ} \mathrm{C}$, equipped with an isocratic pump and photodiode array PDA 2260 detector selected at optimum wavelength of $248 \mathrm{~nm}$. The mobile phase was a mixture of ACN/acetic acid $(30: 70, \mathrm{v} / \mathrm{v})$. It was eluted with a rate of $1 \mathrm{ml} \cdot \mathrm{min}^{-1}$. The injection volume was $130 \mu \mathrm{L}$.

Mineralization of solutions was followed by the reduction of chemical oxygen demand (COD) using the Lovibond ${ }^{\circledR}$ Vario-MD200 Photometer. After oxidation with $\mathrm{K}_{2} \mathrm{Cr}_{2} \mathrm{O}_{7}$ at an acidic $\mathrm{pH}$, quantification of the amount of oxygen required for oxidation of the organic material was carried out at $150^{\circ} \mathrm{C}$ for 2 hours ${ }^{37}$. COD values have been measured colorimetrically using DR/125 spectrophotometer (Hach Company, USA).

For LC/MS analysis of oxidation by-products in the study, we used an LC surveyor HPLC system coupled with an LCQ Advantage triple quadrupole mass spectrometer equipped with a pneumatically assisted electro spray ionization source (ESI) in positive ion mode and a Waters photodiode array detector (PDA). A sample volume of $20 \mu \mathrm{L}$ was injected into Inertsil BDS Hypersil $\mathrm{C} 18(150 \times 2.1) \mathrm{mm} \times 5 \mu \mathrm{m}$ column which thermostated at $35{ }^{\circ} \mathrm{C}$. the mobile phase was a mixture of water/ formic acid - methanol/formic acid $0.1 \%$ with gradient program as follows: $0 \mathrm{~min} 90 \% \mathrm{~A} ; 1 \mathrm{~min}$ $90 \%$ A; $21 \min 40 \%$ A, 26 min 0\% A36 min 0\% A; 37 min $90 \%$ A; 57 min $90 \%$. The flow rate was equal to $0.2 \mathrm{~mL} \mathrm{~min}{ }^{-1}$ and Detection was performed at 200-600 nm.

The biological oxygen demand was measured by an Oxdirect BSB BOD Lovibond thermostated at 20 ${ }^{\circ} \mathrm{C}$. The $\mathrm{pH}$ of the samples was adjusted to a value between 6.5 and 7.5 after the addition of the bacterial seed and the necessary nutrients for bacterial growth. We note that we used domestic wastewater obtained from National Office of Electricity and Drinking Water, Rabat, Morocco and all the experiments are aerated to reach oxygen saturation.

\section{Results and Discussion}

\section{Kinetic study of PRA degradation}

The effect of the current applied to the oxidative degradation was studied for $200 \mathrm{ml}$ of the aqueous solution of PRA $(0.13 \mathrm{mM})$ with $0.1 \mathrm{mM}$ of $\mathrm{Fe}^{2+}$ at $\mathrm{pH}$ 3. According to the results in Figure 1, the kinetics of degradation is accelerated by increasing the applied current from 30 to $100 \mathrm{~mA}$. This influence can be explained by the increase in the speed of the electrochemical reactions 1 and 3, leading to the generation of more ${ }^{\bullet} \mathrm{OH}$. The complete disappearance of PRA was observed at $9 \mathrm{~min}, 7 \mathrm{~min}$, and $4 \mathrm{~min}$ for $30,60,100 \mathrm{~mA}$, respectively. Therefore, $100 \mathrm{~mA}$ appears to be the optimal value of the current.

It was also observed that the decrease in PRA concentration can be described by a pseudo-first order reaction kinetics. The values of the apparent rate constants were determined by $0.57 \mathrm{~min}^{-1}$ $\left(\mathrm{R}^{2}=0.972\right)$ for $30 \mathrm{~mA}, 0.73 \mathrm{~min}^{-1}\left(\mathrm{R}^{2}=0.967\right)$ for $60 \mathrm{~mA}$, and $2.13 \mathrm{~min}^{-1}\left(\mathrm{R}^{2}=0.999\right)$ for $100 \mathrm{~mA}$. Increasing $\mathrm{k}_{\text {app }}$ is related to an expected acceleration of the production of ${ }^{\bullet} \mathrm{OH}$. The value of $\mathrm{k}_{\mathrm{app}}$ for 300 $\mathrm{mA}\left(0.88 \mathrm{~min}^{-1}\right)$ was significantly lower compared to that of $100 \mathrm{~mA}$. This can be explained by the acceleration of wasteful reactions at higher current values such as reduction of $\mathrm{O}_{2}$, evolution of $\mathrm{H}_{2}$ at the 
cathode or oxidation of $\mathrm{H}_{2} \mathrm{O}_{2}$ at the anode (reactions

$$
\begin{aligned}
& \mathrm{O}_{2}+4 \mathrm{e}^{-}+4 \mathrm{H}^{+} \rightarrow 2 \mathrm{H}_{2} \mathrm{O} \\
& 2 \mathrm{H}_{2} \mathrm{O}+2 \mathrm{e}^{-} \rightarrow \mathrm{H}_{2}+2 \mathrm{OH}^{-} \\
& \mathrm{H}_{2} \mathrm{O}_{2} \rightarrow \mathrm{O}_{2}+2 \mathrm{H}^{+}+2 \mathrm{e}^{-}
\end{aligned}
$$
4, 5 and 6).

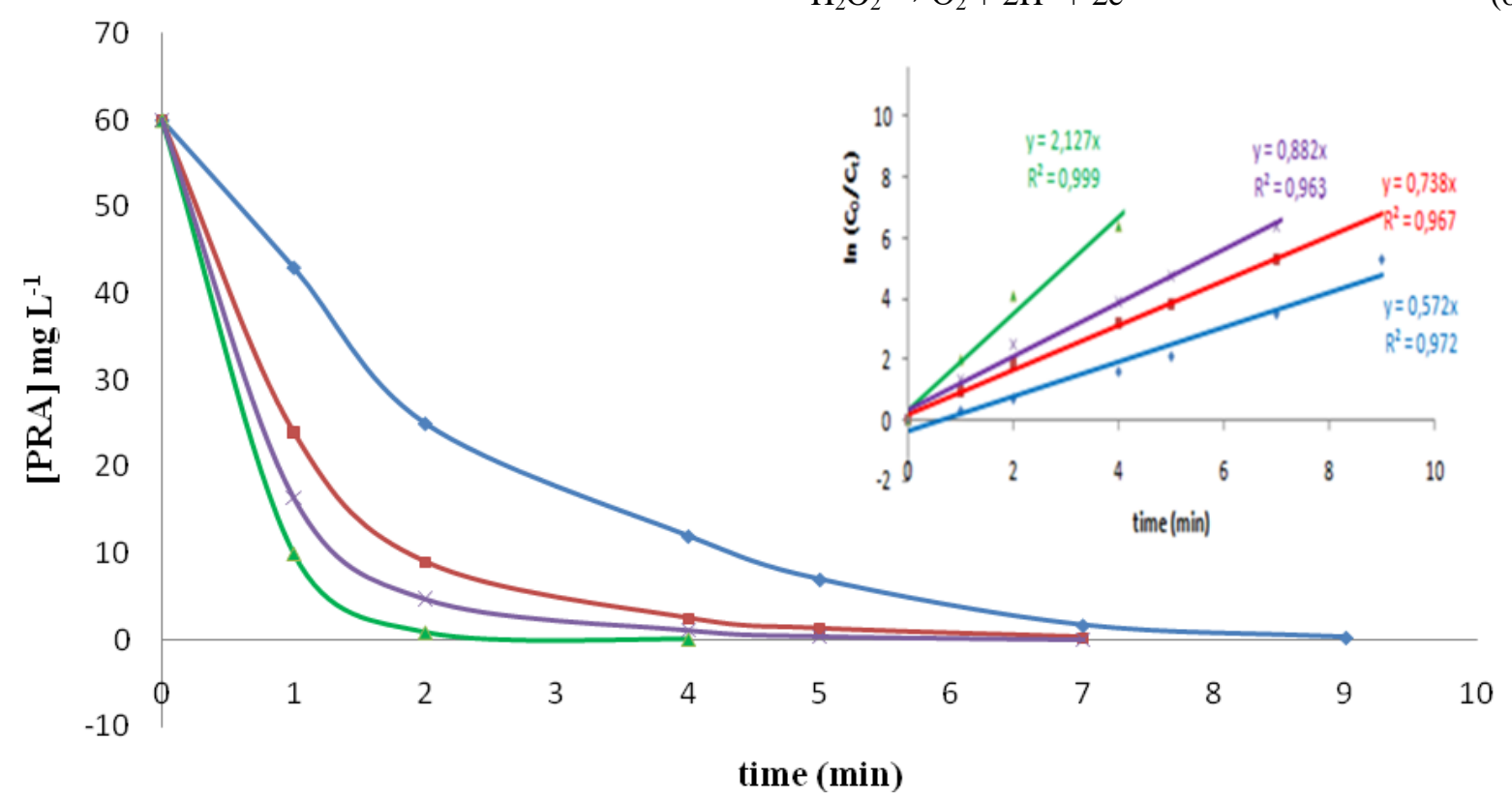

Figure 1. Effect of the current applied on PRA concentration decay by Electro-Fenton treatment at $\mathrm{pH} 3$ in $0.05 \mathrm{M} \mathrm{Na}_{2} \mathrm{SO}_{4}$ and $0.1 \mathrm{mM} \mathrm{Fe}{ }^{2+}$. Applied current I (mA): $30(-\downarrow), 60(--), 100\left(-\boldsymbol{\Delta}_{-}\right), 300(-\times-)$.

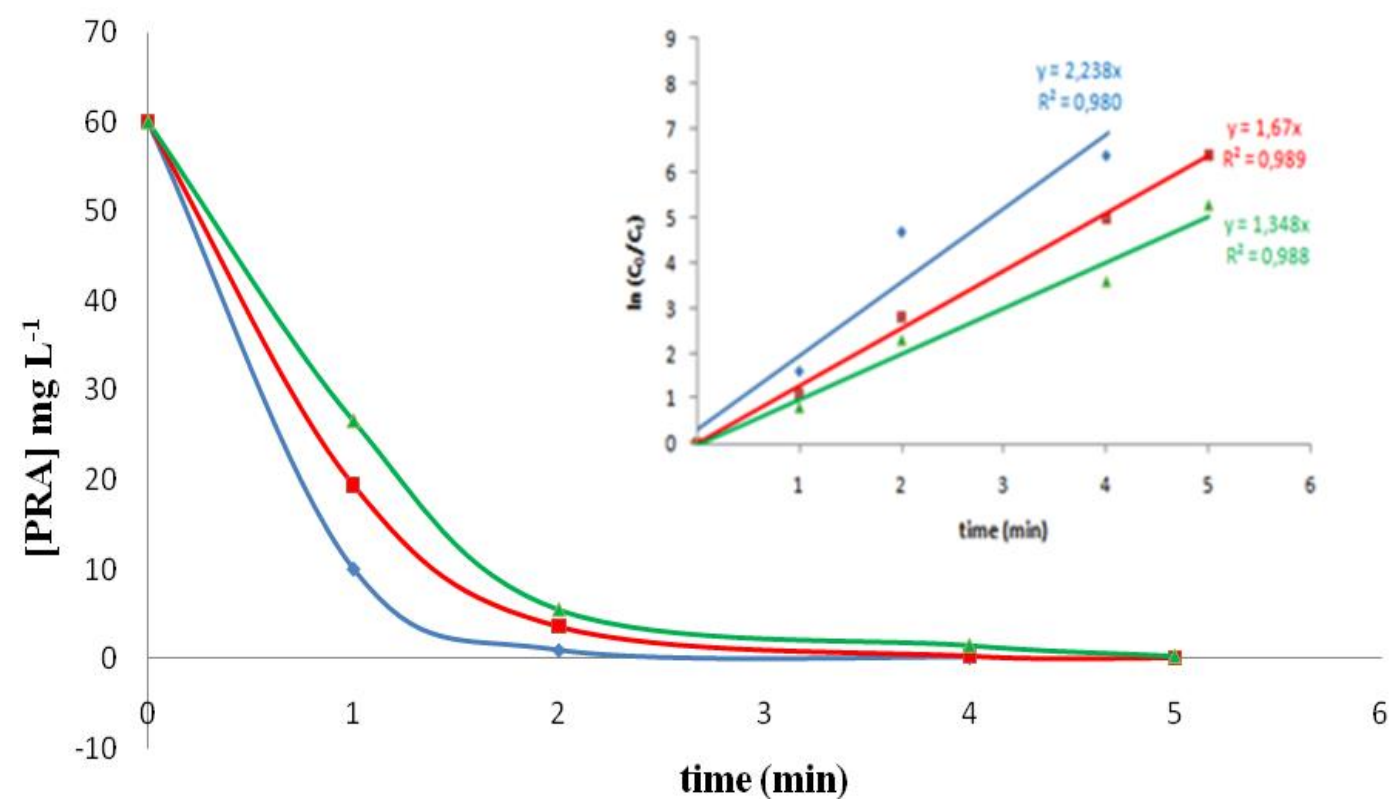

Figure 2. Effect of catalyst concentration $\mathrm{Fe}^{2+}$ on PRA concentration decay during Electro-Fenton treatment in $0.05 \mathrm{M} \mathrm{Na}_{2} \mathrm{SO}_{4}$ at $\mathrm{pH} 3$ and applied current $100 \mathrm{~mA}$. [Fe $\left.{ }^{2+}\right]=0.1 \mathrm{mM}(--), 0.2 \mathrm{mM}(--), 0.5 \mathrm{mM}(-\boldsymbol{\Delta})$.

The catalyst concentration $\mathrm{Fe}^{2+}$ is another important parameter in EF process. Degradation of $0.13 \mathrm{mM}$ of PRA was studied in the presence of various concentrations of $\mathrm{Fe}^{2+}$ at $\mathrm{pH} 3$ and applying a constant current of $100 \mathrm{~mA}$. The results are reported in Figure 2.

The complete disappearance of PRA was reached at $4 \mathrm{~min}$ for catalyst concentration $0.1 \mathrm{mM}$ and $5 \mathrm{~min}$ for catalyst concentrations $0.2 \mathrm{mM}$ and $0.5 \mathrm{mM}$. The higher apparent rate constant was observed for $0.1 \mathrm{mM}\left(2.23 \mathrm{~min}^{-1}\right)$. In contrast, the decrease of this value was observed for $0.2 \mathrm{mM}$ $\left(1.67 \mathrm{~min}^{-1}\right)$ and $0.5 \mathrm{mM}\left(1.35 \mathrm{~min}^{-1}\right)$. This can be explained by the fact that the highest concentrations of $\mathrm{Fe}^{2+}$ hinder process efficiency due to the improvement in the rate of its reaction with ${ }^{\circ} \mathrm{OH}$ (Reaction 7) ${ }^{37}$ below:

$\mathrm{Fe}^{2+}+{ }^{\bullet} \mathrm{OH} \rightarrow \mathrm{Fe}^{3+}+\mathrm{OH}^{-}$ 


\section{Study of the mineralization process}

The electrolysis of aqueous solutions of PRA was performed to see the evolution of the COD as a function of time and thus study the process of mineralization. Various parameters influence the effectiveness of mineralization, the most important are: $\mathrm{pH}$ of the solution, applied current, catalyst concentration, supporting electrolyte and temperature. Note that the optimum $\mathrm{pH}$ value is about 3 and the sodium sulfate is considered as the best supporting electrolyte ${ }^{38-40}$.

Influence of applied current on the EF

Aqueous solutions of PRA were electrolyzed using $0.05 \mathrm{M} \mathrm{Na}_{2} \mathrm{SO}_{4}, \mathrm{Fe}^{2^{+}}$concentration of $0.1 \mathrm{mM}$ at $\mathrm{pH} 3$ and applied current range between $30 \mathrm{~mA}$ and $300 \mathrm{~mA}$. The results are shown in Figure 3.

As can be seen, an increase in the current applied causes a decrease in COD values. This relation is explained by the generation of hydroxyl radicals from the Fenton reaction (reaction 2) due to increased production of $\mathrm{H}_{2} \mathrm{O}_{2}$ from reaction (1) ${ }^{41-42}$. The degree of reduction of PRA is $68 \%, 82 \%, 93 \%$, $89 \%$ for $30,60,100$ and $300 \mathrm{~mA}$ respectively after 6 hours of treatment. The best current obtained for maximum mineralization is $100 \mathrm{~mA}$. By against it was observed a decrease in the efficiency of the mineralization for the $300 \mathrm{~mA}$, this increase of current probably leads to side reactions 4,5,6 and 7 that harm generation of Fenton's reagent.

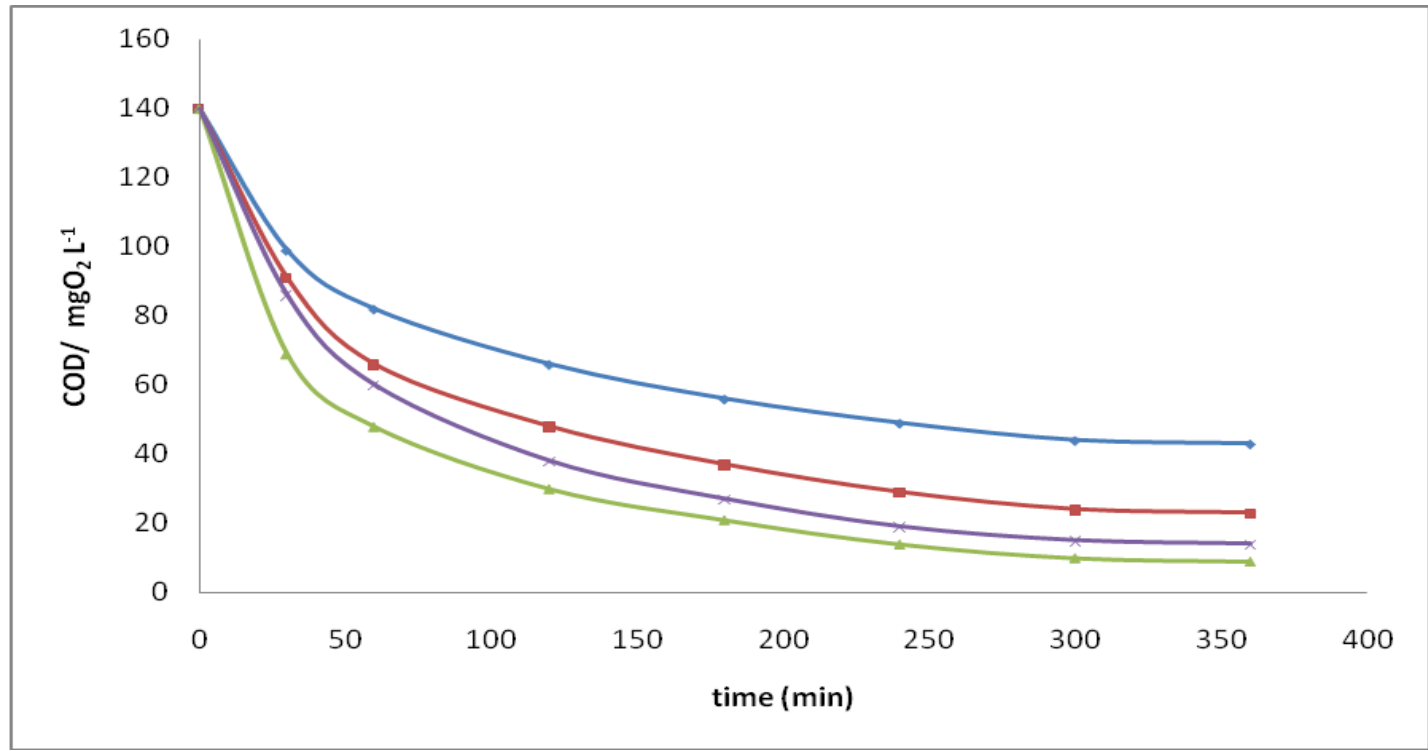

Figure 3. Removal of solution COD as a function of applied current during EF treatment on $0.13 \mathrm{mM}$ PRA in $0.05 \mathrm{M} \mathrm{Na}_{2} \mathrm{SO}_{4}$ at pH 3 and room temperature with $\left[\mathrm{Fe}^{2+}\right]=0.1 \mathrm{mM}$. Applied current (mA): I: $30(-\downarrow-)$, 60(--), 100(-А-) 300(-x-).

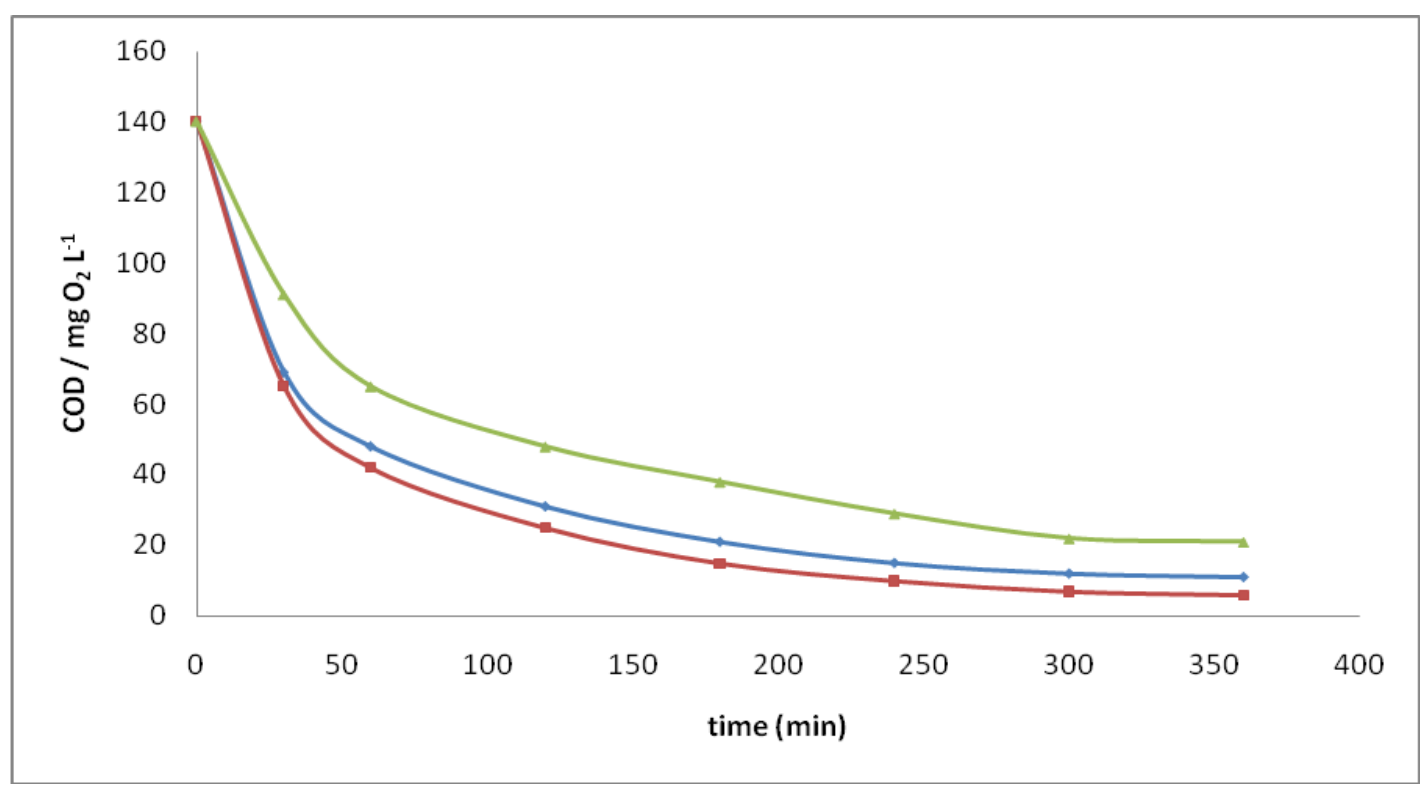

Figure 4. Removal of solution COD as a function of catalyst concentration during EF treatment of $0.13 \mathrm{mM}$ PRA in $0.05 \mathrm{M} \mathrm{Na}_{2} \mathrm{SO}_{4}$ at $\mathrm{pH} 3$ and room temperature with $100 \mathrm{~mA}$. [Fe $\left.\mathrm{Fe}^{2+}\right]=0.1 \mathrm{mM}(-\downarrow) ; 0.2 \mathrm{mM}$

$$
\text { (--); 0.5mM (- } \boldsymbol{\Delta} \text {-) }
$$




\section{Influence of $\mathrm{Fe}^{2+}$ concentration on the $\mathrm{EF}$}

The catalyst concentration $\mathrm{Fe}^{2+}$ is another essential parameter to the Electro-Fenton. Its regulatory effect of the production of hydroxyl radicals ${ }^{\circ} \mathrm{OH}$ of the reaction (2) plays an important role. The influence of this parameter on the degradation of PRA was clarified for $200 \mathrm{ml}$ of $0.13 \mathrm{mM}$ PRA solution using $0.05 \mathrm{M} \mathrm{Na}_{2} \mathrm{SO}_{4}$ at $\mathrm{pH} 3$, $100 \mathrm{~mA}$ and a concentration of $\mathrm{Fe}^{2+}$ between 0.1 and $0.5 \mathrm{mM}$.

These results show the effect of $\mathrm{Fe}^{2+}$ concentration in COD decay. Using $0.2 \mathrm{mM}$ of $\mathrm{Fe}^{2+}$, the oxidation of PRA was accelerated because The formation of radicals ${ }^{\circ} \mathrm{OH}$ Was effective satisfactorily, by the Fenton's reaction (2) 40 Removing $95 \%$ of COD for $6 \mathrm{~h}$ of treatment. The inhibition of the mineralization process at the higher concentration $0.5 \mathrm{mM}$ can be explained by the associated loss of generated ${ }^{\bullet} \mathrm{OH}$ with $\mathrm{Fe}^{2+}$ from the following parasitic reaction $7^{43}$. It has been reported that an excess of ferrous ions would consume hydroxyl radicals 31,44 , for this reason, no improvements have been achieved when an increase on $\mathrm{Fe}^{2+}$ concentration was attained, $0.5 \mathrm{mM}$ removing just $84.2 \%$ of COD.
Apparent Current Efficiency (ACE) is defined as the percentage of applied current utilized to reduce COD:

$\mathrm{ACE} \%=\frac{\left(\mathrm{COD}_{0}-\mathrm{COD}_{\mathrm{t}}\right) \mathrm{FV}}{\text { gIt }} \times 100$

Where $\mathrm{COD}_{0}$ and $\mathrm{COD}_{\mathrm{t}}$ are the COD at times 0

and $\mathrm{t}(\mathrm{s})$, respectively, $\mathrm{F}$ is Faraday's constant $\left(96,487 \mathrm{C} \mathrm{mol}^{-1}\right), \mathrm{V}$ is the volume of the electrolyte $\left(\mathrm{dm}^{3}\right), \mathrm{I}$ is the current (A), and 8 is the equivalent mass of oxygen $\left(\mathrm{g}\right.$. eq $\left.{ }^{-1}\right)$.

In fact, as shown by ACE vs. time curves in Fig. 5, During the electrolytic treatment, ACE decreases over time, ACE values were the highest in the first 30 minutes with $18.31 \%, 10.94 \%, 9.51 \%$, $2.41 \%$ for currents $30,60,100$, and $300 \mathrm{~mA}$ respectively, but decreased significantly during the remainder of the electrolysis duration. This observed decrease could be explained by the decrease in the concentration of aromatic compounds in the solution and subsequently the formation of by-products that are more difficult and resistant to mineralize such as short-chain carboxylic acids, in addition to the domination of parasitic reactions (4) and (6)

\section{Apparent current efficiency}

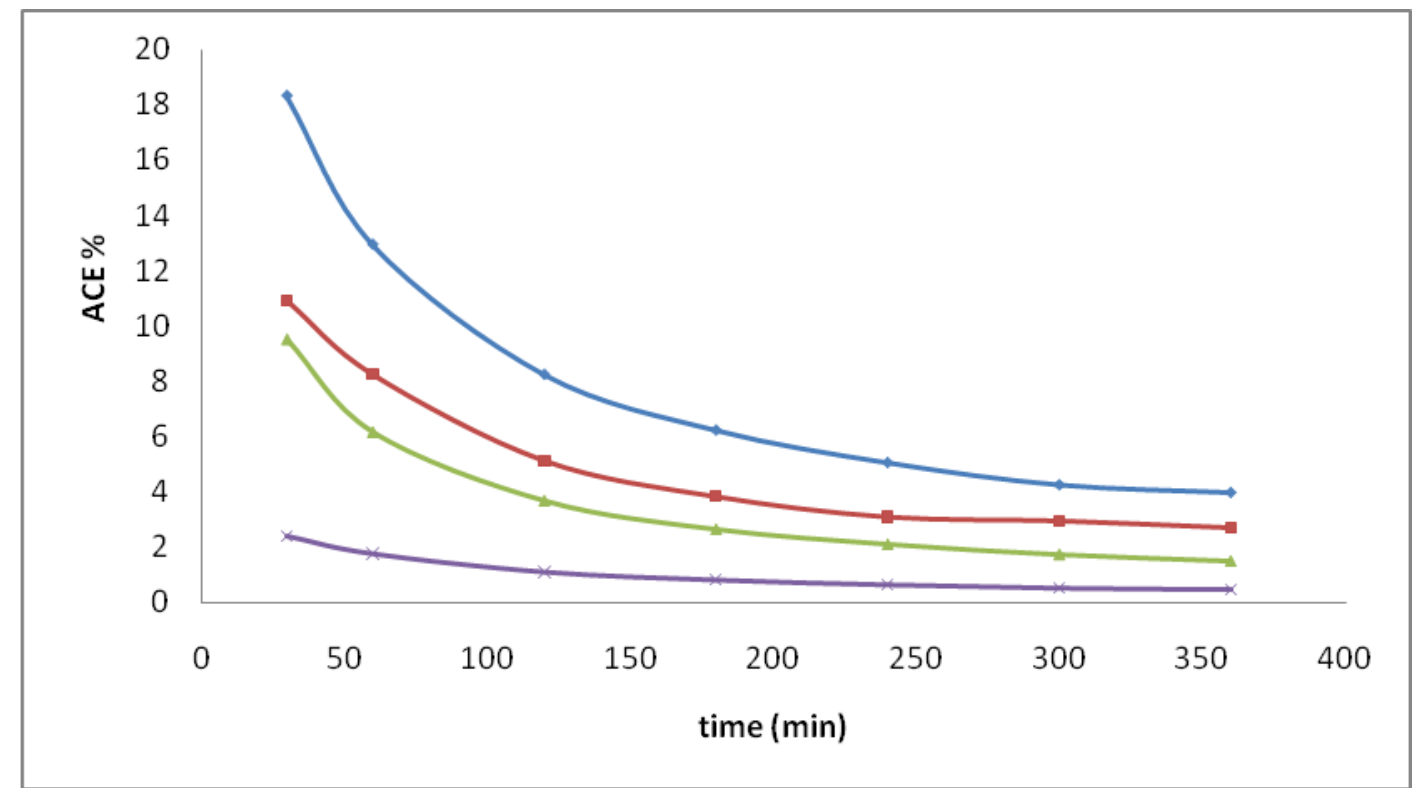

Figure 5. Evolution of ACE \% during EF treatment of $0.13 \mathrm{Mm} P R A$ in $0.05 \mathrm{mM} \mathrm{Na}_{2} \mathrm{SO}_{4}$ at pH 3 and room temperature with $\left[\mathrm{Fe}^{2+}\right]=0.2 \mathrm{mM}$. Applied current (mA): I: $30(-\downarrow-), 60(--), 100(-\mathbf{\Delta}-)$ 300(-X-).

\section{Identification of reaction intermediates}

During our analysis of the samples, the first 10 minutes of the electrolysis were marked by the gradual disappearance of PRA and ROS and training of aromatic intermediates which in turn gradually disappear during the electrolysis. The optimum conditions for the electrolysis of aqueous solutions of ROS are determined according to the results obtained in the study of the degradation of this statin 17. The intermediates obtained were identified by
HPLC according to the European Pharmacopoeia 7.1 and LC/MS. Tables 2 and 3 summarizes the name, molecular formula and characteristics of the identified intermediaries and their HPLC chromatorgrams and mass spectra are given in Figures SI-1, SI-2, SI-3, SI-4 (Supplementary Information at the end).

It should be noted that the pathway of the intermediate products obtained in Tables 2 and 3 formed by the oxidative degradation is illustrated in 
the overall diagram of the elimination of the two statins in the Figures 6 and 7. It comprises two stages; the first step is characterized by the degradation of the product in aromatic intermediates by ${ }^{\bullet} \mathrm{OH}$, followed by the second stage characterized by the presence of aliphatic intermediates which continue to degrade by the attack of the ${ }^{\bullet} \mathrm{OH}$ until the total mineralization $\left(\mathrm{H}_{2} \mathrm{O}+\mathrm{CO}_{2}\right)$.

Table 2. Intermediate products identified using HPLC and LC-MS during the degradation of PRA by EF treatment.

\begin{tabular}{|c|c|c|c|}
\hline $\begin{array}{l}\text { Intermediates } \\
\text { compounds }\end{array}$ & $\mathbf{T}_{\mathrm{R}}(\min )$ & $\mathbf{m} / \mathbf{z}$ & Chemical formula \\
\hline Compound $\mathrm{A}^{\mathrm{a}}$ & 11.16 & 446 & \\
\hline Compound $\mathrm{B}^{\text {a,b,c }}$ & 3.38 & 439 & \\
\hline Compound $\mathrm{D}^{\mathrm{a}, \mathrm{b}, \mathrm{c}}$ & 34.21 & 406 & \\
\hline Compound $E^{\text {a,b,c }}$ & 5.57 & 439 & \\
\hline $1^{d}$ & - & 320 & \\
\hline $2^{e}$ & - & 284.9 & \\
\hline $3^{d}$ & - & 354 & \\
\hline
\end{tabular}

Notes: $\mathrm{a}=$ Obtained by HPLC retention time in agreement with method European Pharmacopoeia 7.1 $\mathrm{b}=$ Obtained by LC/MS in agreement with data reported in S.L. Syed et J. Siji ${ }^{45}$

$\mathrm{c}=$ Obtained by LC/MS in agreement with data reported in S.L. Syed ${ }^{46}$

$\mathrm{d}=$ Obtained by LC/MS in agreement with data reported in B. Ravazi B et al. ${ }^{47}$

$\mathrm{e}=$ Obtained by LC/MS in agreement with data reported in A. Kocijan A et al. ${ }^{48}$ 
Table 3. Intermediate products identified using HPLC and LC-MS during the degradation of ROS by EF treatment.

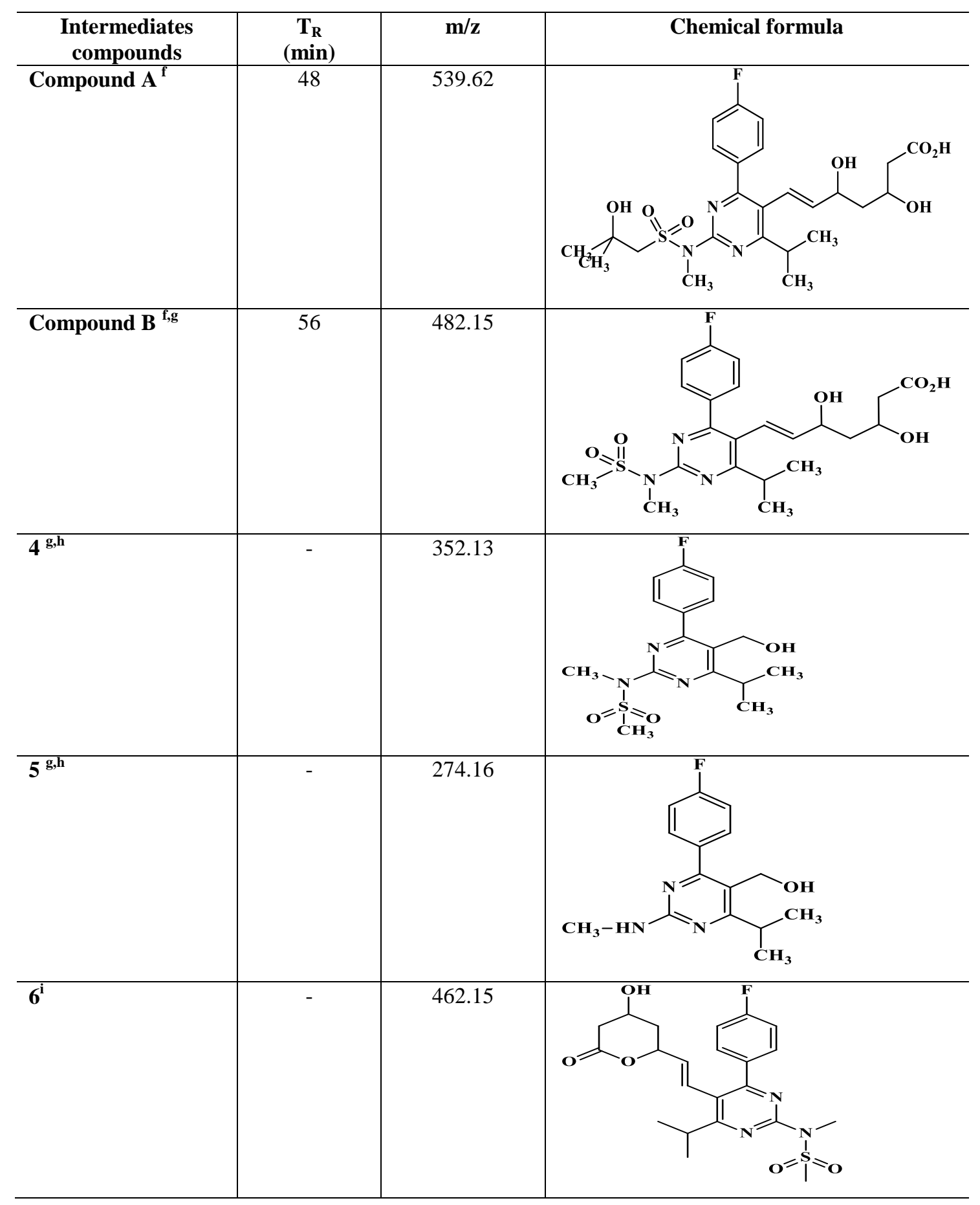

Notes: $\mathrm{f}=$ Obtained by HPLC retention time in agreement with method European Pharmacopoeia 7.1 $\mathrm{g}=$ Obtained by LC/MS in agreement with data reported in T.C. Machado et al. ${ }^{49}$

$\mathrm{h}=$ Obtained by LC/MS in agreement with data reported in J. Segalin et al. ${ }^{50}$

$\mathrm{i}=$ Obtained by LC/MS in agreement with data reported in S. Sulaiman et al. ${ }^{51}$ 


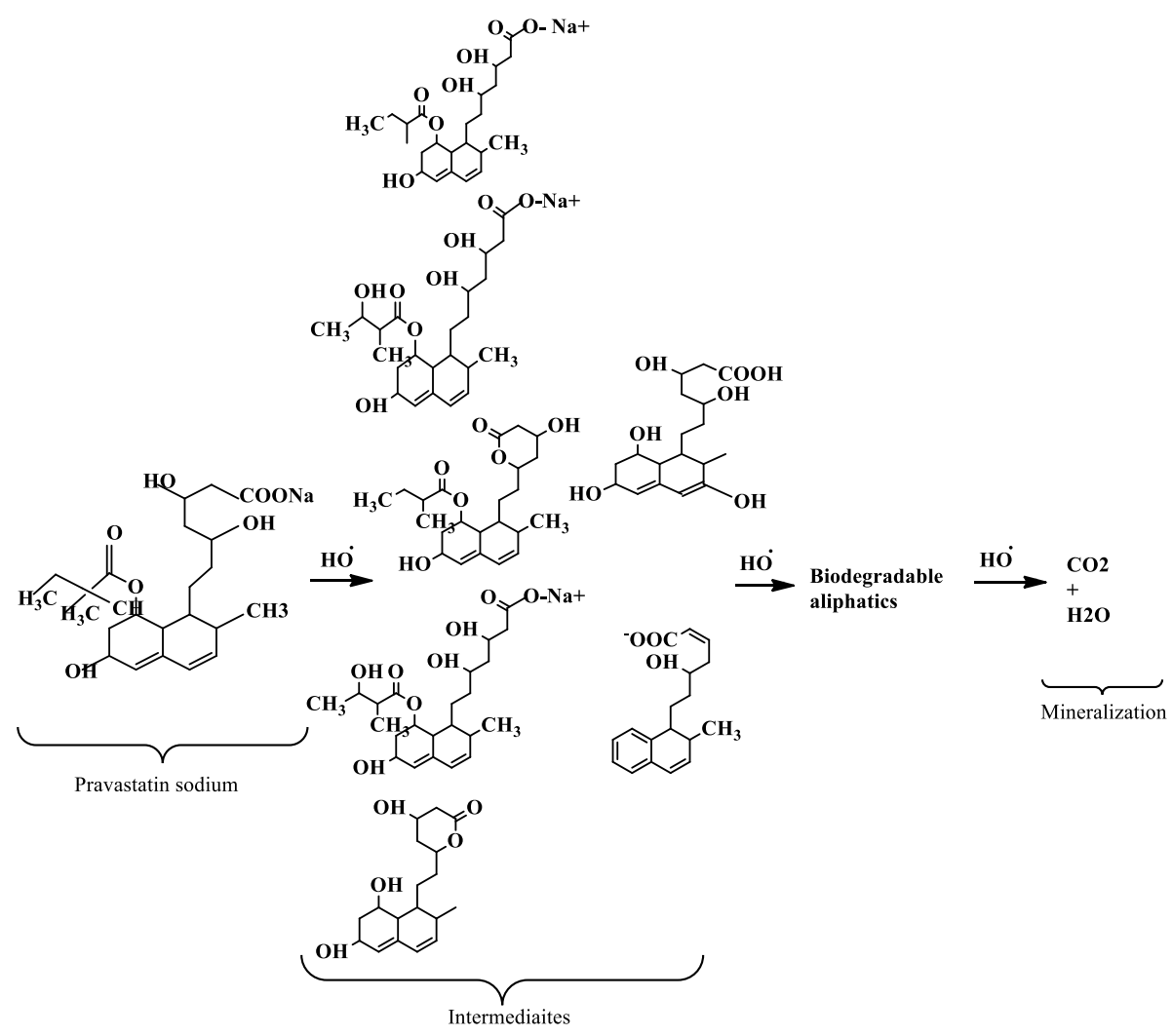

Figure 6. Global diagram of degradation/mineralization of pravastatin in an aqueous medium using the EF process. Optimal conditions $\left(100 \mathrm{~mA},\left[\mathrm{Fe}^{2+}\right]=0.1 \mathrm{mM}\right.$

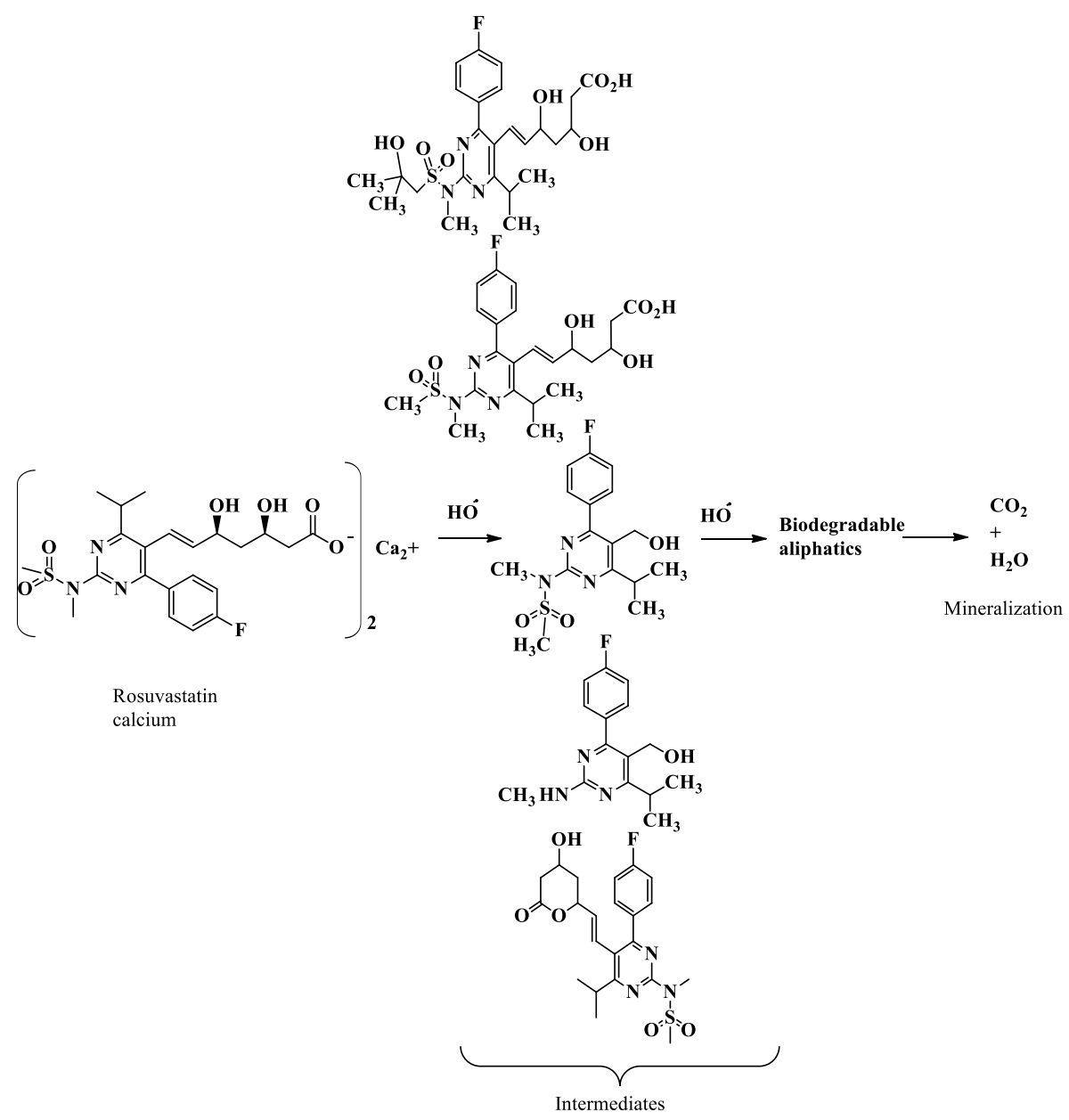

Figure 7. Global diagram of degradation/mineralization of rosuvastatin in an aqueous medium using the EF process. Optimal conditions $\left(300 \mathrm{~mA},\left[\mathrm{Fe}^{3+}\right]=0.1 \mathrm{mM}\right)$ 


\section{Biodegradability assays and Study of feasibility of the coupling EF with the biological treatment}

The biodegradability was characterized by the ratio between Biochemical Oxygen Demand at 5 days $\left(\mathrm{BOD}_{5}\right)$ and $\mathrm{COD}{ }^{52}$. This ratio must be greater than 0.4 to consider that the solution is easily biodegradable ${ }^{53}$. All the bottles containing the solutions were equipped with a rubber sleeve in which 3 to 4 drops of $\mathrm{KOH}$ solution were added to trap the $\mathrm{CO}_{2}$ formed during biodegradation. This generates a decrease in pressure within the system. The samples were incubated at $20{ }^{\circ} \mathrm{C}$ during 5 days in dark conditions.

Although biological treatment is an economically profitable process, its effectiveness is limited by recalcitrant organic compounds and the time required when a long period of acclimation is required. On the other hand, during the mineralization of the recalcitrant organic compounds by electro-Fenton process, the electrical energy consumption and relatively the cost of treatment are even higher than the electrolysis time is quite long. Therefore, the coupling of these two methods allows an effective and less expensive treatment.

The coupling of an advanced oxidation process such as EF to a biological treatment is particularly recommended to improve the biodegradability of a substrate ${ }^{54,55}$. Several studies have confirmed the efficacity of this combination in the elimination of recalcitrant organic compounds 56,57

\section{- Case of PRA}

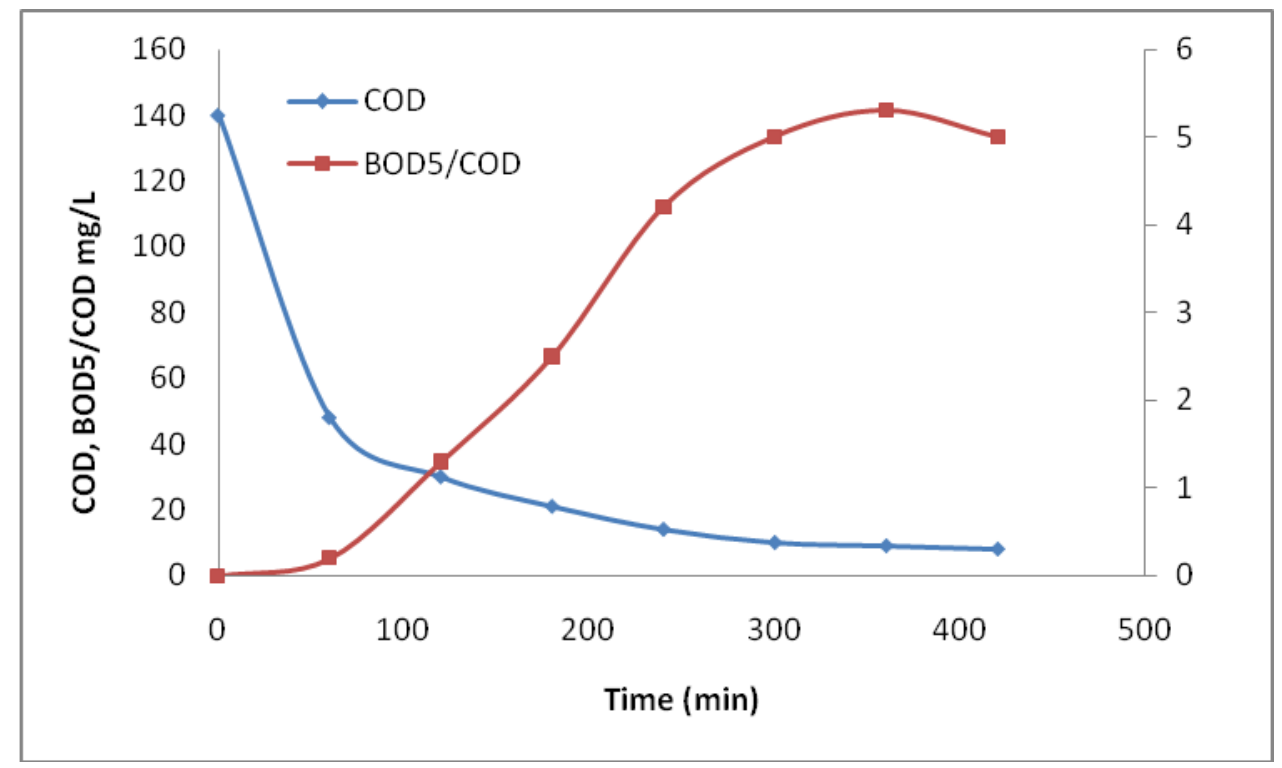

Figure 8. Evolution of $\mathrm{BOD}_{5} / \mathrm{COD}$ ratio and $\mathrm{COD}$ abatement rate during the treatment of $\mathrm{PRA}(\mathrm{I}=100 \mathrm{~mA}$, $\left.\left[\mathrm{Fe}^{2+}\right]=0.1 \mathrm{Mm}\right)$

Exploitation of the results shows that the untreated solutions of PRA are non-biodegradable due to the $\mathrm{BOD}_{5} / \mathrm{COD}$ ratio that tends to 0 and that the biodegradability of PRA increases as the COD decreases at different times during 7 hours of preprocessing (420 $\mathrm{min})$.

After 60 minutes of electrolysis, the biodegradability is still limited since the ratio BOD5/COD is equal to 0.2 . This behavior is mainly due to the total disappearance of PRA and the formation of aromatic intermediates characterized by their toxicity and low biodegradability.

At $120 \mathrm{~min}$, the ratio BOD5/COD increases to 1.3 , this is explained by the formation of readily biodegradable substances such as aliphatic molecules, following the opening of aromatic rings by oxidation reactions.
Finally, from $120 \mathrm{~min}$ to $420 \mathrm{~min}$, the oxidation reactions continue in the medium and consequently improve the biodegradability to 5.3.

According to the results noted previously, it was found that the PRA is non-biodegradable and its total disappearance of the aqueous solutions is after $4 \mathrm{~min}$ of electrolysis by EF (Fig. 1), giving rise to aromatic products still non-biodegradable (Table 3 ) but which can be transformed into biodegradable aliphatic intermediates as the oxidation by ${ }^{\bullet} \mathrm{OH}$ continues. It should also be noted that the mineralization of solutions of PRA gave an abatement rate equal to $78 \%$ after 2 hours of treatment while the remaining $22 \%$ requested a longer time (5 hours) to reach complete mineralization. explaining the presence of aliphatic products characterized by their resistance to the mineralization by ${ }^{\circ} \mathrm{OH}$, thus requiring a large energy consumption. 
For this purpose, it implies that EF tends to improve the biodegradability of PRA solutions and could be used as a pretreatment step for biological treatment for 2 hours.

- Case of ROS

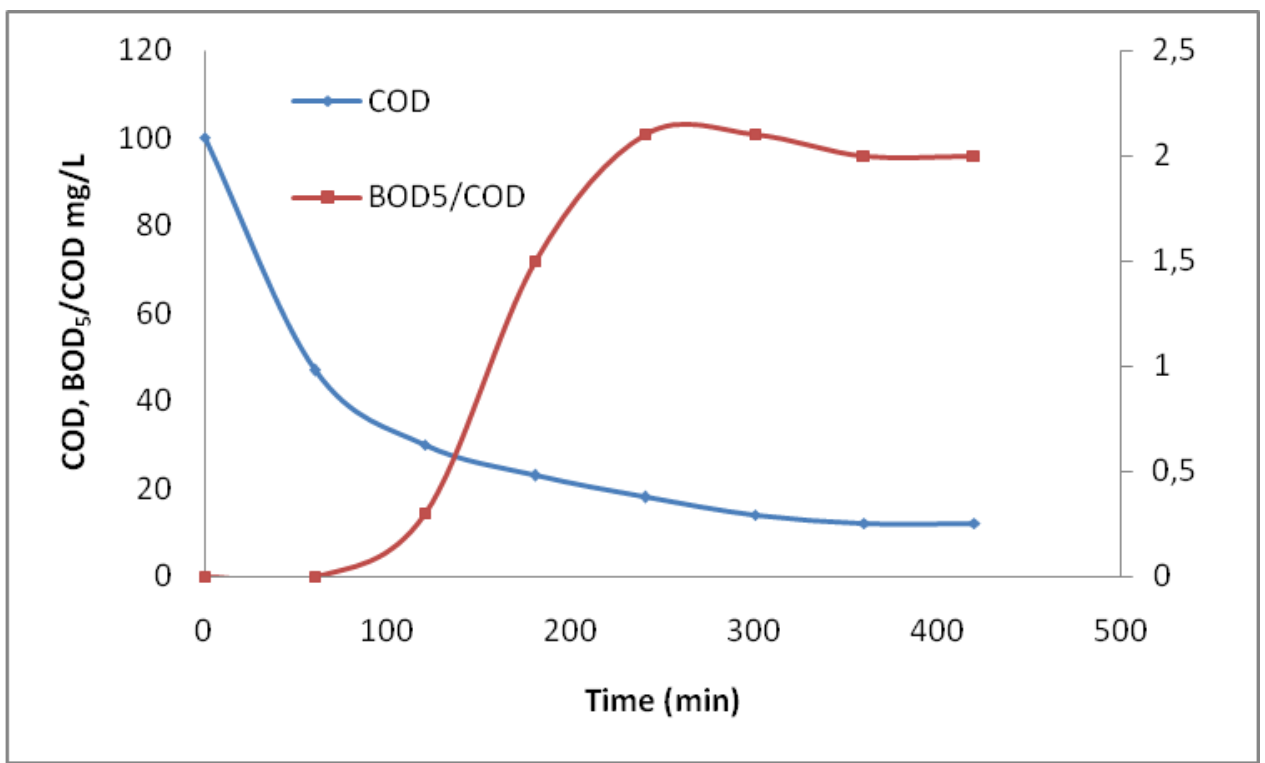

Figure 9. Evolution of $\mathrm{BOD}_{5} / \mathrm{COD}$ ratio and $\mathrm{COD}$ abatement rate during the treatment of $\mathrm{ROS}(\mathrm{I}=300 \mathrm{~mA}$, $\left.\left[\mathrm{Fe}^{2+}\right]=0.2 \mathrm{Mm}\right)$

According to the results, the ROS solution is non-biodegradable at the beginning and at $60 \mathrm{~min}$ of the electrolysis with a $\mathrm{BOD}_{5} / \mathrm{COD}$ ratio equal to 0 . A very slight increase of the biodegradability was observed after $120 \mathrm{~min}$ of the electrolysis with a BOD5 / COD ratio of 0.3, thus showing that the primary and aromatic by-products are relatively resistant to microorganisms. However, an easily biodegradable solution was obtained with a ratio of 1.5 after $180 \mathrm{~min}$, this can be explained by the transformation of the aromatic intermediates into biodegradable aliphatic products following oxidation by the hydroxyl radicals generated.

On the other hand, the mineralization rate of the ROS solutions reached $77 \%$ after 3 hours of treatment, while the remaining $23 \%$ mineralized completely after 4 hours of electrolysis because of the difficulty of oxidizing the by-products. aliphatic by ${ }^{\circ} \mathrm{OH}$, resulting in a high consumption of unnecessary energy that can be avoided by involving biological treatment after 3 hours of EF electrolysis.

\section{Conclusion}

In this study, we employed Electro-Fenton process to oxidize PRA, the experiments were performed using cells with a carbon felt cathode and Pt anode. They show that $\mathrm{Fe}^{2+}$ and applied current have an important effect in EF. The degradation of this statin followed pseudo-first order reaction kinetics. The highest COD removal was achieved when a current of $100 \mathrm{~mA}$ is applied in the presence of $0.2 \mathrm{mM} \mathrm{Fe}{ }^{+}$at $5 \mathrm{~h}$ of treatment. A number of stable intermediate products have been identified for PRA and ROS using HPLC and LC-MS analyses.
Biodegradability tests shows that the relevance of EF pretreatment has been confirmed and electrolysis of 180 min of the ROS solution and $120 \mathrm{~min}$ of the PRA solution is required for efficient biological treatment.

\section{References}

1- S. K. Khetan, T.J. Collins, Human pharmaceuticals in the aquatic environment: a challenge to green chemistry. Chem. Rev, 2007, 107, 2319-2364.

2- A.W. Garrison, J. D. Pope, F. R. Allen, GC/MS analysis of organic compounds in domestic wastewaters, in: C. H. Keith(Ed), Identification and analysis of organic pollutans in water, Ann Arbor Science Publishers, Ann Arbor, MI, 1976, 517-556.

3- C. Hignite, D.L. Azarnoff, Drugs and drugs metabolites as environmental contaminants: chlorophenoxyisobutyrate and salicylic acid in sewage water effluent, Life Sci , 1977, 20, 337-341

4- M.L. Richardson, J.M. Bowron, the fate of pharmaceutical chemicals in the aquatic environment, J. Pharm. Pharmacol, 1985, 37, $1-12$.

5- I. Sirés, C. Arias, P. L. Cabot, F. Centellas, J. A. Ganido, R.M. Rodriguez, E. Brillas, Degradation of clofibric acid in acidic aqueous medium by electro-Fenton, Chemosphere, 2007, 66, 1660-1669.

6- N. Vieno, T. Tuhkanen, L. Kronbeg, Elimination of pharmaceuticals in sewage 
treatment plants in Finland water Res, 2007, 41, 1001-1012.

7- V. Hamem, L. Santos, Degradation and removal methods of antibiotics from aqueous matrices A review.J. Environ. Manage, 2011, 92, 2304-2347.

8- X.S. Miao, C.D. Metcalfe, Determination of cholesterol-lowering statin drugs in aqueous samples using liquid chromatographyelectrospray ionization tandem mass spectrometry, J.Chromaogr. A, 2003, 998, 133-141.

9- S. Sleijfer, A.Van der Goast, A. Planting, G. Stoter, J. Verweij, The potential of statins as part of anti-cancer treatment, J.Cancer, 2005, 41, 516-522.

10- P. Grobelny, V. Giampietro, D. Vidaldi, F. Dall'Acqua, J. Mielcarek, Photostability of Pitavastatin A novel HMG-CoA reductase inhibito, Journal of pharmaceutical and biomedical analysis, 2009, 50, 597-601.

11- M.D. Hernando, A. Aguera, A.R. FernandezAlba, LC-MS analysis and environmental risk of lipid regulators, Anal Bioanal Chem, 2007, 387, 1269-1285.

12- M. Piecha, M. Sarakha, P. Trebse, Photocatalytic degradation of cholesterollowering station drugs by $\mathrm{TiO}_{2}$-based catalyst.kinetics, analytical studies and toxicity evaluation, J Photochem Photobiol A, 2010, 213, 61-69.

13- M. Klavarioti, D. Mantzavinos, D. Kassinos, Removal of residual pharmaceuticals from aqueous systems by advanced oxidation processes. Environ Int, 2009, 35, 402-417.

14- R. Andreozzi, V. Caprio, R. Marotta, D. Vogna, Paracetamol oxidation from aqueous solution by means of ozonation and $\mathrm{H}_{2} \mathrm{O}_{2} / \mathrm{UV}$ system. Water Res, 2003, 37, 993-1004.

15- I. Arsalan-Alaton, S. Dogrul, Pretreatment of penicillin formulation effluent by advanced oxidation processes, J Hazard Mater, 2004, 112, 105-113.

16- E.S. Elmolla, M. Chaudhuri, Degradation of amoxicillin, ampicillin and cloxacillin antibiotics in aqueous solution by the $\mathrm{UV} / \mathrm{ZnO}$ photocatalytic process, J Hazard Mater ,2010, 173,445-9.

17- N. Beqqal, M. Sh. Yahya, M. EL Karbane, A. Guessous, K. El Kacemi, Kinetic study of the degradation/mineralization of aqueous solutions contaminated with Rosuvastatin drug by Electro-Fenton: Influence of experimental parameters, J. Mater. Environ.Sci, 2017, 8(12), 4399-4407.

18- T.G. Vasconcelos, D.M. Henriques, A. König, A.F. Martins, K. Kümmerer, Photodegradation of the antimicrobial ciprofloxacin at high $\mathrm{pH}$ : identification and biodegradability assessment of the primary by-products, Chemosphere, 2009, 76, 487-493.
19- L. Ge, C. Halsall, C. Chen, P. Zhang, Q. Dong, $\mathrm{Z}$. Yao, Exploring the aquatic photodegradation of two ionisable fluoroquinolone antibiotics Gatifloxacin and balofloxacin: Degradation kinetics, photoproducts and risk to the aquatic environment, Sci. Total Environ, 2018, 633, 1192-1197.

20- M.A. Oturan, J.J. Aaron, Advanced oxidation processes in water/wastewater treatment: principles and applications: a review.Crit.Rev.Environ.Sci.Technol , 2014, 44, 2577-2641.

21- W. Melliti, M. Errami, R. Salghi, A. Zarrouk, Lh. Bazzi, H. Zarrok, B. Hammouti, S. S. AlDeyab. S. Fattouch, F. Raboudi, Electrochemical Treatment of Aqueous Wastes Agricole Containing Oxamyl by BDD-Anodic Oxidation, Int. J. Electrochem. Sci, 2013, 8, $10921-10931$.

22- M. Skoumal, C. Arias, P.L. Cabot, F. Centellas, J.A. Garrido, R.M. Rodriguez, E. Brillas, Mineralization of the biocide chloroxylenol by electrochemical advanced oxidation processes. Chemosphere, 2008, 71(9), 1718-1729.

23- M. Murati, N. Oturan, J.J. Aaron, A. Dirany, B. Tassin, Z. Zdravkovski, M.A. Oturan, Degradation and mineralization of sulcotrione and mesotrione in aqueous medium by the electro-Fenton process: a kinetic study, Environ. Sci. Poll. Res, 2012, 19, 1563-1573.

24- M.A. Oturan, N. Oturan, C. Lahitte, S. Trevin, Production of hydroxyl radicals by electrochemically assisted Fenton's reagent. Application to the mineralization of an organic micropolluant, the pentachlorophenol, J. Electroanal.Chem, 2001, 507, 96-102.

25- H. Zhang, C. Fei, D. Zhang, F. Tang, Degradation of 4-nitrophenol in aqueous medium by electro-fenton method, J. Hazard. Mater, 2007, 145, 227-232.

26- E.J. Ruiz, C. Arias, E. Brillas, A. HernndezRamirez, J.M. Peralta Pernandez, Mineralization of acid Yellow 36 azo dye by electro-fenton and solar photoelectron-fenton processes with boron-doped diamond anode. Chemosphere, 2011, 82, 495-501.

27- M.C. Edelahi, N.Oturan, K. El kacemi, J.J. Aaron, M.A. Oturan, Kinetics of oxidative degradation/mineralization pathways of the phenylurea herbicides diuron, monuron and fenuron in water during application of the electrofenton process, Appl catalysis B: Environ, 2010, 97, 82-89.

28- A. Kesraoui, N. Bellakhal, N. Oturan, M. Dachraoui, M.A. Oturan, Treatment of a mixture of three pesticides by photo-and electro-fenton process, Desalination, 2010, 250, 450-455.

29- Y. Sh. Muna, M. El Karbane, N. Oturan, K. El Kacemi, M.A. Oturan, Mineralization of the antibiotic levofloxacin in aqueous medium by electro-Fenton process: kinetics and 
intermediate products analysis, Environmental Technology,2016, 37:10, 1276-1287.

30- M. Sh. Yahya, N. Oturan, K. El Kacemi, M. El Karbane, C.T. Aravindakumar, Oxidative degradation study on antimicrobial agent ciprofloxacin by electro-fenton process: Kinetics and oxidation products, Chemosphere, 2014, 117, 447-454.

31- M. Sh. Yahya, N. Beqqal, A. Guessous, M.R. Arhoutane, K. El Kacemi, Degradation and mineralization of moxifloxacin antibiotic in aqueous medium by electro-Fenton process: Kinetic assessment and oxidation products. Cogent Chemistry, 2017, 3:1290021.

32- M. Sarakha, P. Trebse, M. Piecha, Photocatalytic degradation of cholesterollowering statin drugs by $\mathrm{TiO}_{2}$-based catalyst.Kinetics, analytical studies and toxicity evaluation, Journal of photochemistry and photobiology A: Chemistry, 2010, 213, 61-69.

33- T.C. Machado, T.M. Pizzolato, A. Arenzon, J. Segalin, M.A. Lansarin, Photocatalytic degradation of rosuvastatin: analytical studies and toxicity evaluations, Science of the total environ, 2015, 502, 571-577.

34- J. Mielcarek, M. Kula, R. Zych, P. Grobelny, kinetis studies of fluvastatin photodegradation in solutions, React. Kinet. Catal. Lett, 2005, 86, 119-126.

35- R.P Shah, A Sahu, S Singh, LC-MS/TOF, LC$\mathrm{MS}^{\mathrm{n}}$, on-line H/D exchange and LC-NMR studies on rosuvastatin degradation and in silico determination of toxicity of its degradation products: a comprehensive approach during drug development, Anal. Bioanal. Chem, 2013, 405, 3215-3231.

36- E. Brillas I. Sirès, M.A. Oturan, Electrofenton process and related electrochemical technologies based on fenton's reaction chemistry. Chem. Rev, 2009, 109, 6570-6631.

37- F. Fourcade, S. Yahiat, K. Elandaloussi, S. Brosillon, A. Amrane, Relevance of photocatalysis prior to biological treatment of organic pollutants-selection criteria, Chem. Eng. Technol, 2012, 35, 238-246.

38- M. Bobu, S. Wilson, T. Greibrokk, E. Lundanes, I. Siminiceanu, Comparison of advanced oxidation processes and identification of monuron photodegradation products in aqueous solution, Chemosphere, 2006, 63, 1718-1727.

39- A. Özcan, Y. Sahin, A.S. Koparal, M.A. Oturan, A comparative study on the efficiency of electro-Fenton process in the removal of propham from water, Appl. Catal. B, 2009, 89, 620-626.

40- M. Panizza, M.A. Oturan, Degradation of Alizarin Red by electro-Fenton process using a carbon-felt cathode. Electrochim. Acta, 2011, 56, 7084-7087.

41- S.C. Elaoud, M. Panizza, G. Cerisola, T. Mhiri, Coumaric acid degradation by electro-Fenton process, Journal of Electroanalytical Chemistry, 2012, 667, 19-23.

42- C. Flox, S. Ammar, C. Arias, E. Brillas, A.V. Vargas-Zavala, R. Abdelhedi, Electro- Fenton and photoelectro-Fenton degradation of indigo carmine in acidic aqueous medium, Applied Catalysis B: Environmental, 2006, 67, 93-104.

43- S. Hammami, N. Bellakhal, N. Oturan,

N. Oturan, A., Dachraoui, M.,2008.

Degradation of Acid Orange 7 by electrochemically generated_OH radicals in acidic aqueous medium using a boron-doped diamond of platinum anode A mechanistic study. Chemosphere 7,678-684.

44- Y. Sun, J.J Pignatello, Photochemical reactions involved in the total mineralization of $2,4-\mathrm{D}$ by iron (3+)/ hydrogen peroxide/UV.

Environmental Science \& Technology,1993, 27, 304-310.

45- S. L. Syed, J. Siji, USP purity analysis of pravastatin sodium using the Agilent 1120 compact LC Agilent technologies Bangalore, India, publication number 5989-9869EN, 2010.

46- S.L. Syed, Assessment of in-process impurities in pravastatin using the Agilent 6410 Triple Quadrupole LC/MS in negative mode, Agilent technologies Bangalore, India, publication number 5989-9343EN, 2008.

47- B. Razavi, W. Song, H. Santoke, W.J. Cooper, Treatment of statin compounds by advanced oxidation processes: kinetic considerations and destruction mechanisms, radiation physics and chemistry, 2011, 80, 453-464.

48- A. Kocijan, R. Grahek, L. Zupanéié- Kralj, Identification of an impurity in Pravastatin by Application of Collision-Activated Decomposition Mass spectra, acta chim slov, 2006, 53, 464-468.

49- T.C. Machado, T.M. Pizzolato, A. Arenzon, J. Segalin, M.A. Lansarin, Photocatalytic degradation of rosuvastatin: Analytical studies and toxicity evaluations. Science of the Total Environment, 2015, 502, 571-577.

50- J. Segalin, C. Sirtori, L. Jank, M.F.S. Lima, P.R. Livotto, T.C. Machado, A.M. Lansarin, T.M. Pizzolato, Identification of transformation products of rosuvastatin in water during $\mathrm{ZnO}$ photocatalytic degradation through the use of associated LC-QTOF-MS to computational chemistry Journal of Hazardous Materials, 2015, 299, 78-85.

51- S. Sulaiman, M. Khamis, S. Nir, F. Lelario, L. Scrano, R. Karaman, Stability and Removal of Several Statins from Wastewater Using Different Treatment Technologies, International Case Studies Journal, 2015, 4(6), 32-50.

52- A. Tegzea , G. Ságia ,K. Kovácsa ,R. Homloka ,T.Tótha, C. Mohácsi-Farkasd, L. Wojnárovitsa, E. Takácsa, Degradation of fluoroquinolone antibiotics during ionizing radiation treatment and assessment of antibacterial activity, toxicity and 
biodegradability of the products. Radiation Physics and Chemistry, 2018, 147,101-105.

53- N.A. Salles, F. Fourcade, F. Geneste, D. Floner, A. Amrane, Relevance of an electrochemical process prior to a biological treatment for the removal of an organophosphorous pesticide, phosmet, J. Hazard. Mater, 2010, 181, 617-623.

54- C. Comninellis, A. Kapalka, S. Malato, S.A. Poulios, I. Mantzavinos, Advanced oxidation process for water treatment: advances and trends for R\&D. J. Chem Technol Biotechnol, 2008, 83, 769-776.

55- P. Núñez, H.K. Hansen, N. Rodríguez,

J. Guzmán, C. Gutiérrez, Electrochemical generation on Fenton`s reagent to treat spent caustic wastewater. Separ. Sci. Technol, 2009, 44, 2223-2233.

56- S. Khoufi, F. Aloui, S. Sayadi, Pilot scale hybrid process for olive mill wastewater treatment and reuse, Chem. Eng. Process, 2009, 48, 643-650.

57- M R. Arhoutane, M Sh. Yahya, M. El Karbane, A. Guessous, H. Chakchak, K. El Kacemi, Removal of pyrazinamide and its by-products from water: Treatment by electro-Fenton process and feasibility of a biological posttreatment, Mediterr.J.Chem., 2019, 8(1), 53-65. 
SUPPLEMENTAY INFORMATION

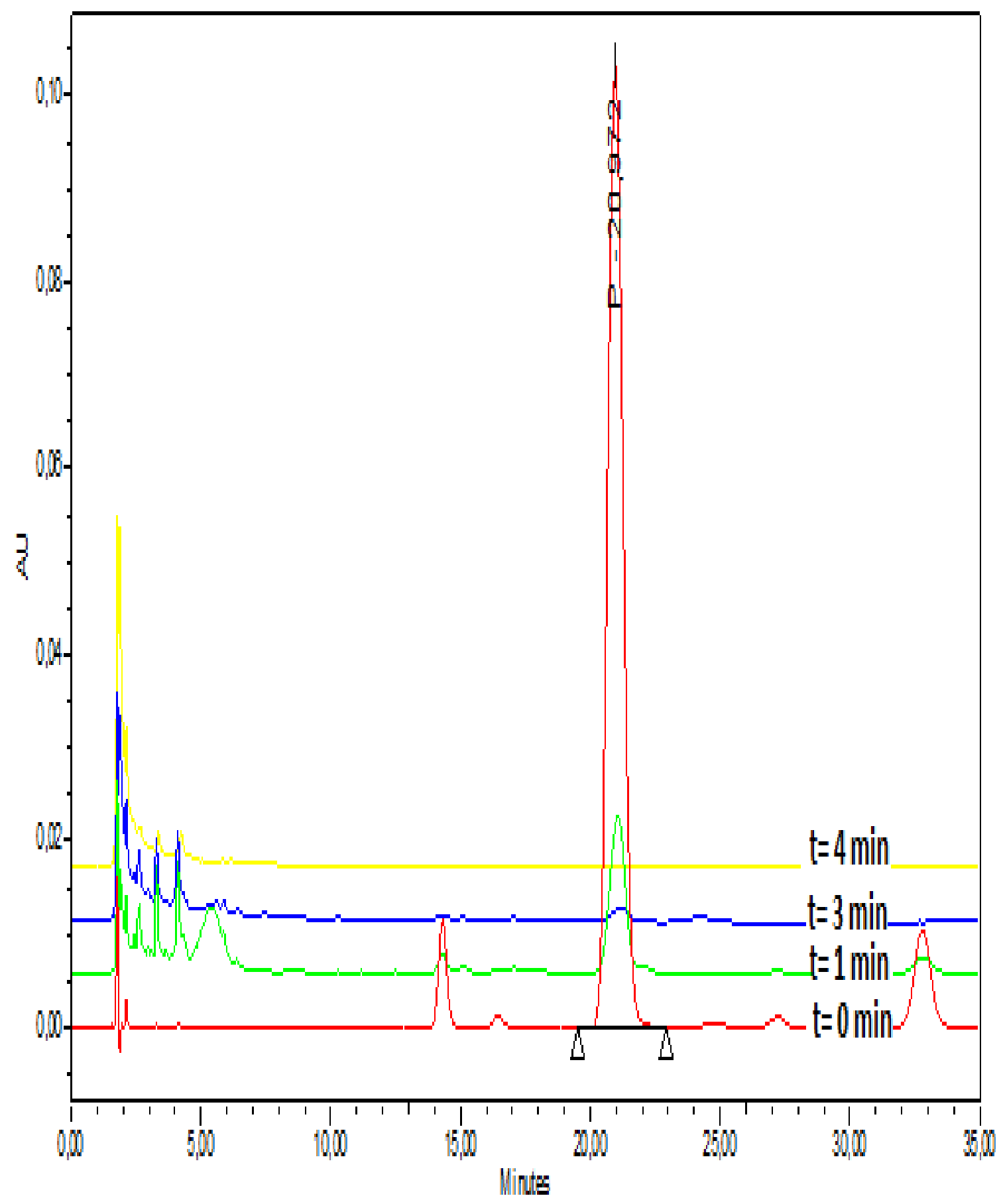

Figure SI-1. Chromatograms showing the decrease of the existence of pravastatin in the solution during the first 5 min of treatment by electro-Fenton process. $\left[\mathrm{Fe}^{2+}\right]=0.1 \mathrm{mM}, \mathrm{I}=100 \mathrm{~mA},\left[\mathrm{Na}_{2} \mathrm{SO}_{4}\right]=0.05 \mathrm{M}, \mathrm{V}=$ $200 \mathrm{ml}$. 


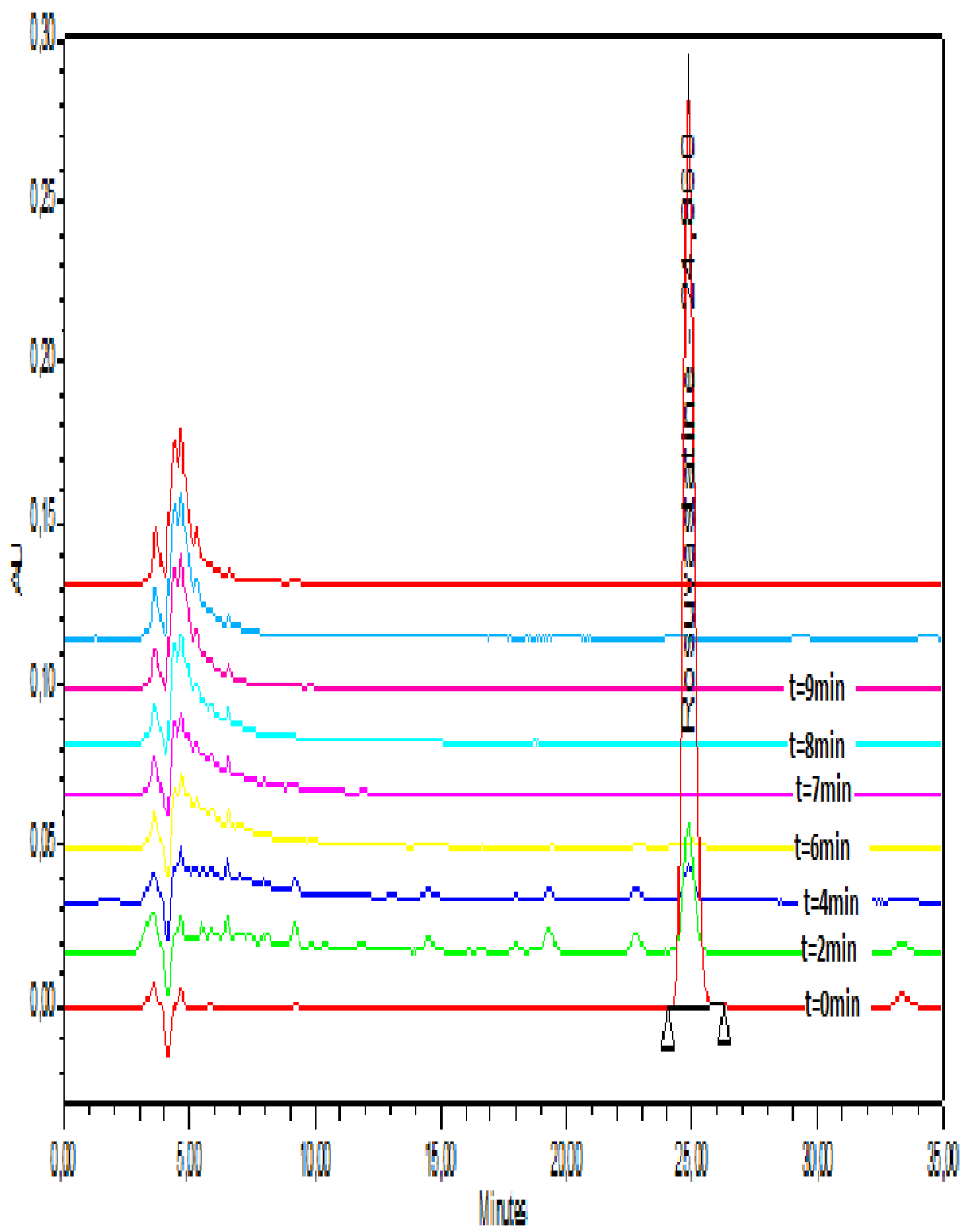

Figure SI-2. Chromatograms showing the decrease of the existence of rosuvastatin in the solution during the first $15 \mathrm{~min}$ of treatment by electro-Fenton process. $\left[\mathrm{Fe}^{2+}\right]=0.1 \mathrm{mM}, \mathrm{I}=300 \mathrm{~mA},\left[\mathrm{Na}_{2} \mathrm{SO}_{4}\right]=$ $0.05 \mathrm{M}, \mathrm{V}=200 \mathrm{ml}$ 

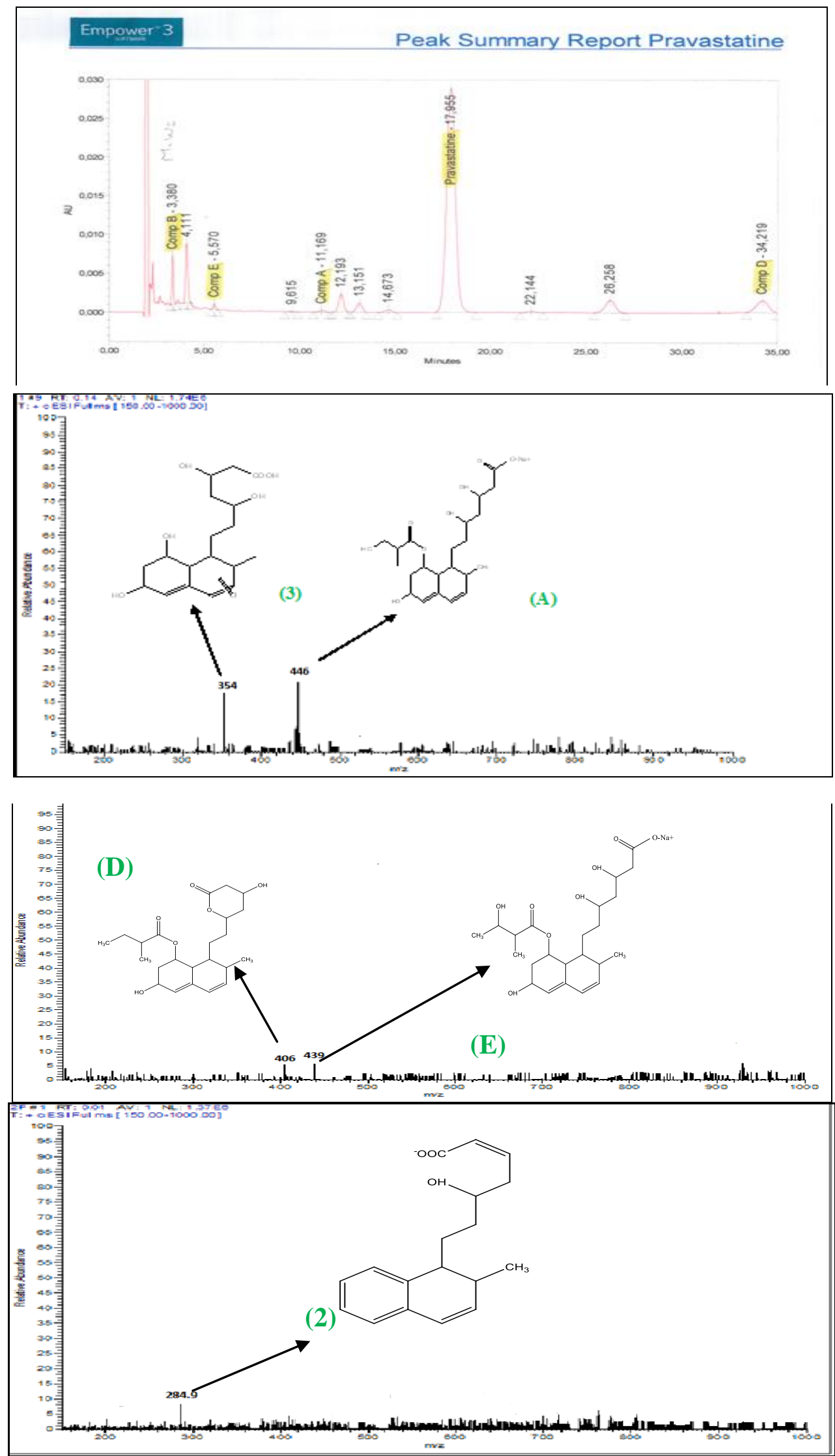

Figure SI-3. (A, B, D, E,1,2) HPLC chromatogram and Mass spectra of intermediate products present in the solution during $1 \mathrm{~h}$ of mineralization by electro-Fenton process of PRA. $\left[\mathrm{Fe}^{2+}\right]=0.1 \mathrm{mM}, \mathrm{I}=100 \mathrm{~mA}$, 

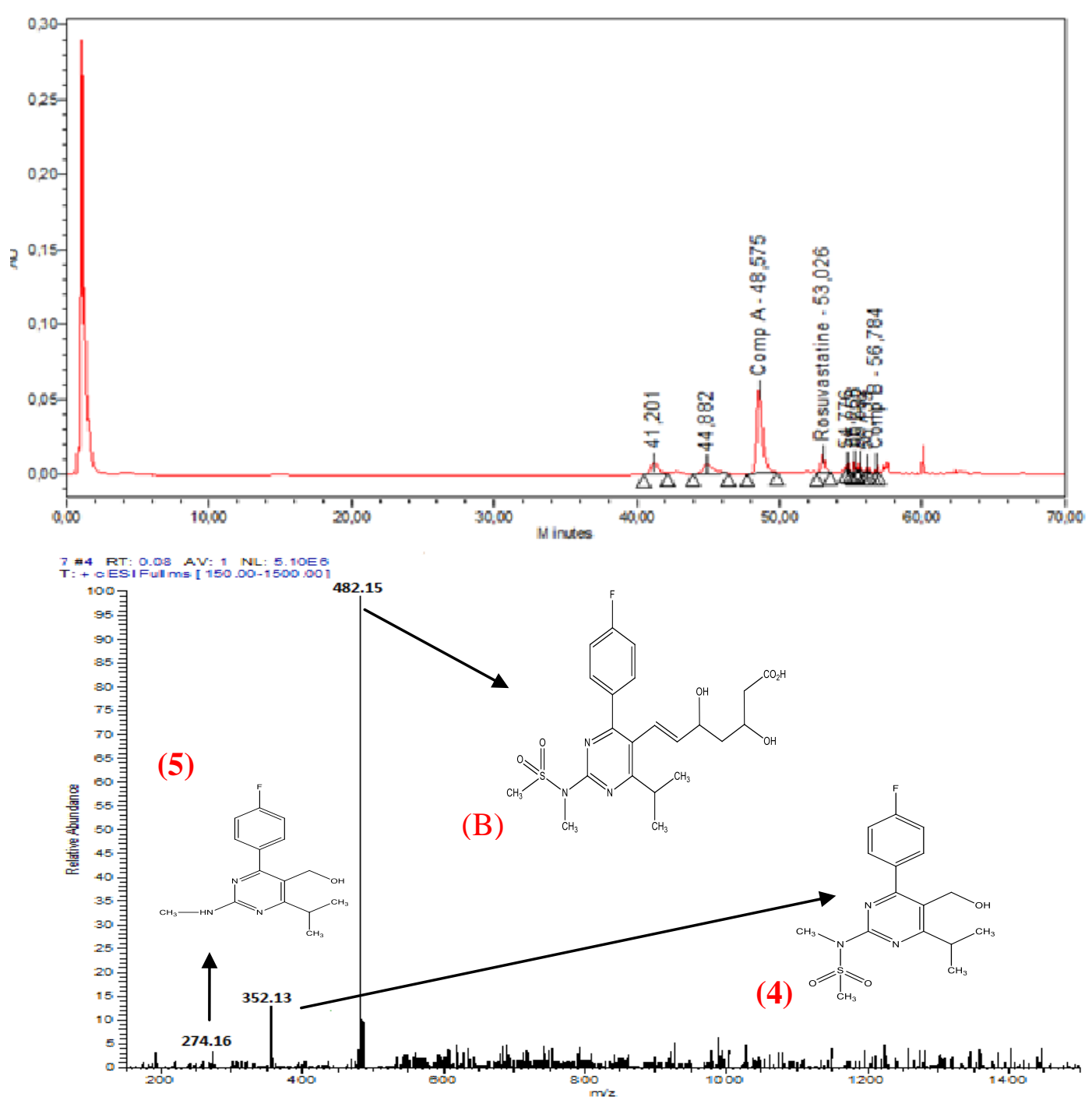

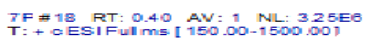

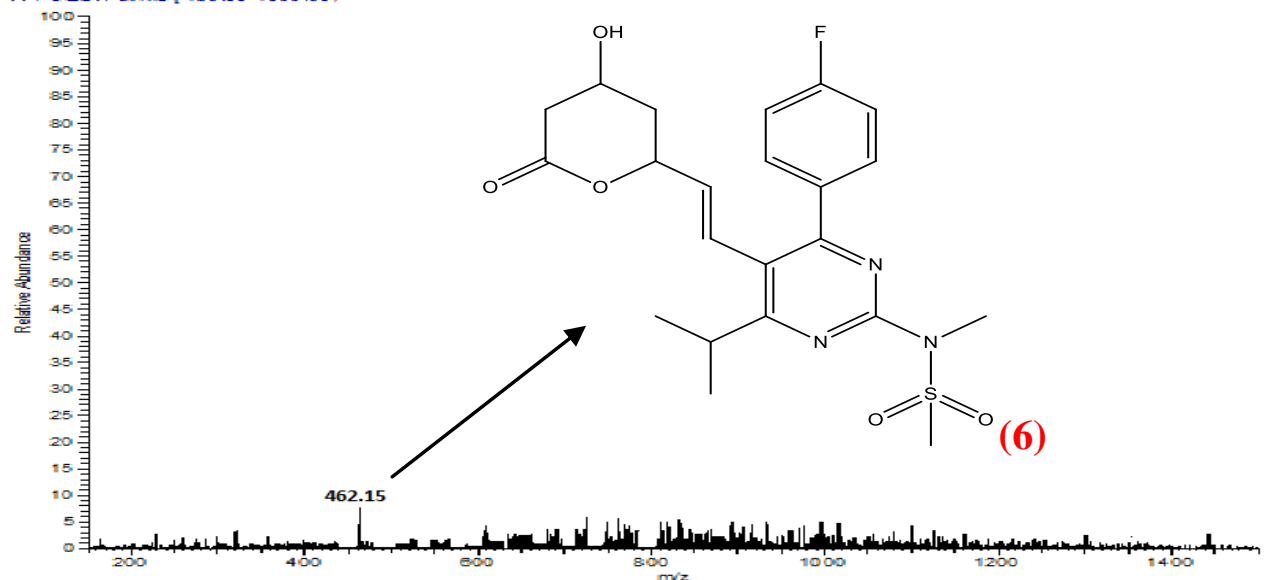

Figure SI-4. (A, B, 4,5,6) HPLC chromatogram and Mass spectra of intermediate products present in the solution during $1 \mathrm{~h}$ of mineralization by electro-Fenton process of $\mathrm{ROS}$. $\left[\mathrm{Fe}^{2+}\right]=0.1 \mathrm{mM}, \mathrm{I}=300 \mathrm{~mA}$, 